\title{
أحسكام النفث
}

$$
\begin{aligned}
& \text { إعداد } \\
& \text { د ـبلدرية عبدالله علي الفاملدي } \\
& \text { أستاذ مساعد - جامعة الملك سعود بن عبدالعزيز } \\
& \text { للعلوم الصحية - الرياض }
\end{aligned}
$$




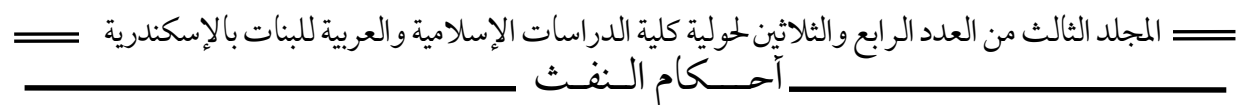

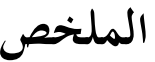

أن المراد بالنفث نفخ لطيف بلا ريق أو بريق خفيف وهو أقل من التفل.

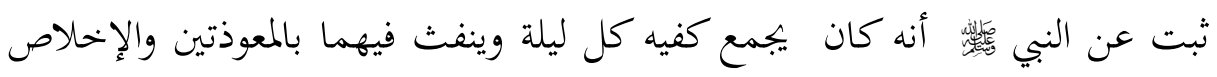

$$
\text { ويمسح ما استطاع من جسده ثلاث مرات. }
$$

ثبت عن الببي

$$
\text { من أهله نفث عليه أيضاً. }
$$

أن النفث يمكن أن يكون قبل القراءة أو بعدها فالأمر في ذلك واسع.

لا يشترط النفث في الرقية ، فتصح بلا نفث كما ورد عن النبي لئس فعل ذلك.

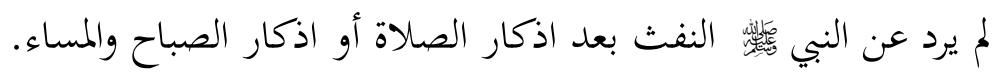

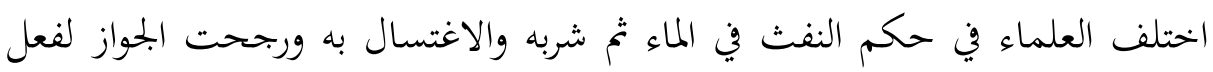

السلف ذلك.

لا ينبغي التوسع في أمر الرقية الشرعية واتخاذها مهنة ووسيلة للتكسب ، ولا النفث

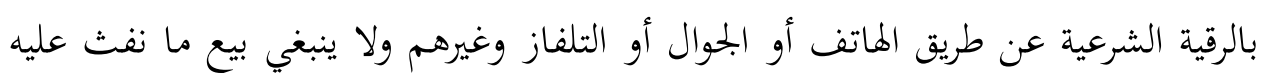

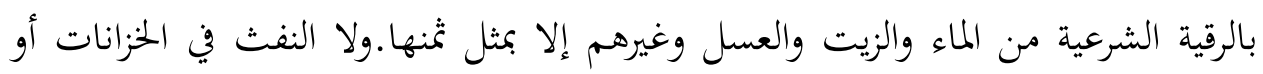

$$
\text { الكميات الكبيرة من الماء. }
$$

لا ينبغي للنافث أن ينفث إذا علم أن به مرضاً معدياً.

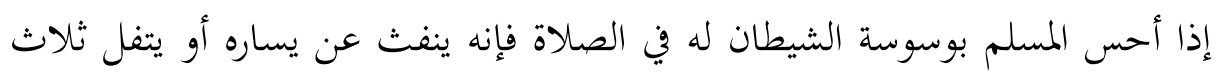

$$
\text { مرات مع الاستعاذة بالله من الشيطان الرجيم. }
$$

إذا رأى النائم ما يكره في منامه ينفث أو يتفل أو يبصق عن يساره ثلاث مرات مرات

$$
\text { ويستعيذ بالله من شرها. }
$$




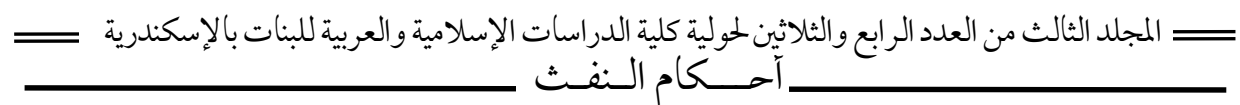

\section{Summary}

It is intended to inflate a nice blower without a luster or light luster, which is less than a cough.

that he gathered his hand every night and breathed in them with the meanings and sincerity and wiped out what he could of his body three times. $\mathrm{It}$ is proven from the Prophet

The Prophet (peace and blessings of Allaah be upon him) was proven that if he complained about the same, he would have to be punished.

It can be done before or after reading.

It is not required to do tafsat in al-Rukiya, so it is advised that there should be no expiation as stated by the Prophet. The Prophet (peace and blessings of Allaah be upon him) did not respond to the Prophet (peace and blessings of Allaah be upon him).

The scholars differed concerning the ruling on blowing water in water, then drinking it and ghusl, and it is permissible to do so.

It is not necessary to expand the order of the sharia law and take it as a profession and means of earning, nor to expel the legitimate shar'i by phone, mobile or television, etc. It is not necessary to sell what is expended on the legitimate sharqiyah of water, oil, honey and others except for its price.

The hypnotherapist should not breathe if he is aware that he has contagious disease.

If a Muslim senses that he is the devil in prayer, he spits on his left or takes care three times with seeking refuge in Allah from the accursed Satan.

If the sleeper sees what he hates in his sleep, he spits or spits or spits on his left three times and seeks refuge in God from her evil. 


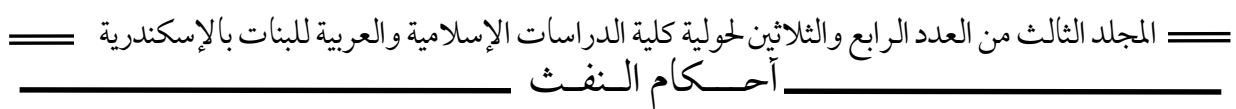

\section{بسم الله الرحمن الرحيم}

الحمد لله رب العالمين ، والصلاة والسلام على أشرف الأنبياء والمرسلين ،سيدنا ونبينا وإمامنا

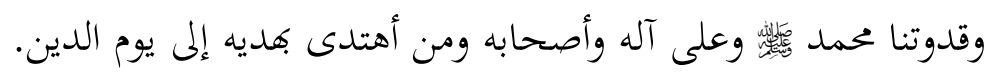
أما بعد: - ما

كثر الحديث في عصرنا حول موضوع العلاج بالرقى الشرعية ، بسبب كثرة الأمراض بالعين والسحر وغيرهما من الأمراض النفسية والجسدية ، التي عجز الطب الحديث عن معالجتها من جهة ، ومن جهة أخرى ظهر من يدعي العلاج بالرقية الشرعية من المشعوذين والسحرة الذين خلطوا الرقية بالسحر والشركيات ، وأيضاً الجهال والنفعيين الذين يستغلون حاجة الناس للعلاج بدون علم ولا دراية بهذا الباب. على أن الميدان ماحلا من المحتسبين الصادقين الذي نفع الله بهم وبرقيتهم.

ولكن أختلط الأمر على الناس بين الأول والثاني ، بسبب عدم العلم والمعرفة بضوابط الرقية الشرعية ، التوسع المذموم في أمور الرقية بحيث أصبحت بتحارة رابحة ومهنة للبعض تدر عليهم مبالغ كبيرة وأدخلوا فيها كثير من البدع والخرافات ، مما جعل البعض ينكر الرقية الشرعية ويصفها بالتخلف والرجعية. ومن الأشياء التي توسع فيها البعض بسبب الجهل مسألة النفث في الرقية الشرعية ، سواءً النفث على الجسد ، أو الماء وغيرهما من العسل والزيت.

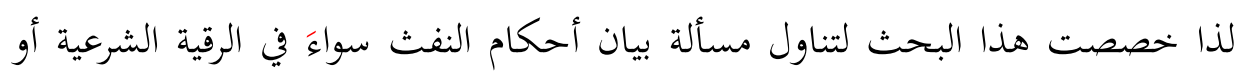
غيرها من المواضع التي ذكر فيها النفث. أسأل الله العون والتوفيق والسداد. 


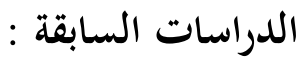

بعد البحث والتحري لم أجد من أفرد هذا الموضوع ببحث مستقل ، وغاية ما وجدته فتاوى في الرقية الشرعية بشكل عام ، تشمل فتاوى عن النفث في الرقية وجُمعت هذه الفتاوى في

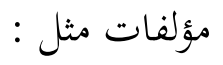

ا (الفتاوى الذهبية في الرقى الشرعية ) من أجوبة سماحة الشيخ عبدالعزيز بن باز ، والشيخ محمد بن صالح العثيمين ، والشيخ عبدالله الجبرين وفتاوى اللجنة الدائمة. r. الزبدة السلفية في الرقية الشرعية لعالم العين والسحر والجحان. فتاوى لسماحة الشيخ عبد العزيز بن باز ، والشيخ محمد بن ناصر الدين الألباني ، والشيخ محمد بن صالح العثيمين ، والشيخ محمد بن ابراهيم آل الشيخ رحمهم الله جميعاً ،والشيخ

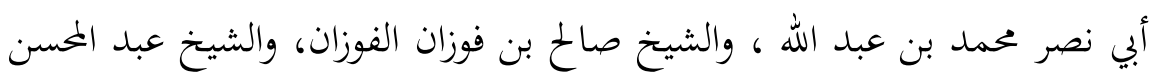
العباد حفظهم الله ، واللجنة الدائمة للبحوث العلمية والإفتاء أو كتب تتحدث عن أحكام الرقية الشرعية وعن عالم الجن ،وكيفية علاج من أصيب بالعين والمس والسحر و وسائل التحصين من السحر والعين ،.مثل: r. كتاب ( فتح الحق المبين في علاج الصرع والسحر والعين ) للدكتور عبدالله الطيار كوالشيخ سامي بن سليمان المبارك. ـ. كتاب (فتح الحق المبين في أحكام رقى الصرع والسحر والعين ) لإبي البراء أسامة

$$
\text { بن ياسين المعاني. }
$$

التمهيد: في تعريف النفث والألفاظ ذات الصلة و فيه ثلاثة مطالب: المطلب الأول: تعريف النفث وفيه ثلاثة مسائل. المسألة الأولى: تعريف النفث في اللغة. 


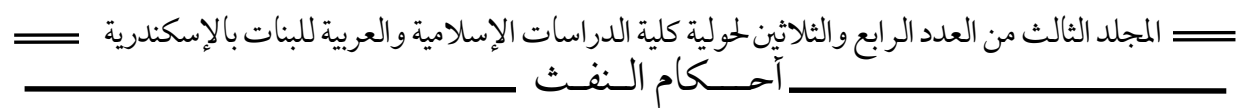

المسألة الثانية : تعريف النفث في الاصطلاح.

المسألة الثالثة: العلاقة بين المعنيين.

المطلب الثاني : الألفاظ ذات الصلة.

المطلب الثالث: صفة النفث.

المبحث الأول: النفث على الجسد ، وفيه ستة مطالب:

المطلب الأول: نفث الإنسان في كفية ومسح الجحد عند النوم، وفيه ثلاث مسائل:

المسألة الأولى: ما الذي يمسح من البدن؟

المسألة الثانية : هل المسح على الثياب أو البدن؟

المسألة الثالثة : كم عدد مرات المسح أو القراءة والنفث؟

المطلب الثاني : حكم النفث في الرقية.

المطلب الثالث : هل النفث قبل القراءة أو بعدها ؟

المطلب الرابع : النفث بالمعوذتين والمسح بعد كل صلاة.

المطلب الخامس : النفث في الكفين والمسح عند قراءة أذكار الصباح والمساء.

المطلب السادس: النفث عن طريق الهاتف أو الجوال أو التلفاز وغيرهم من وسائل

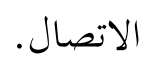

المبحث الثاني: النفث في الماء وفيه أربعة مطالب:

المطلب الأول: النفث في الماء بالرقية الشرعية وشربه والاغتسال به.

المطلب الثاني: الجمع بين أحاديث النهي عن النفخ في الماء و بين من يرى جواز

$$
\text { النفث فيه. }
$$

المطلب الثالث: الوضوء و الاغتسال بالماء الذي نفث فيه بالرقية الشرعية في دورات

$$
\text { المياه. }
$$

المطلب الرابع : كمية الماء الذي ينفث فيه بالرقية الشرعية. 


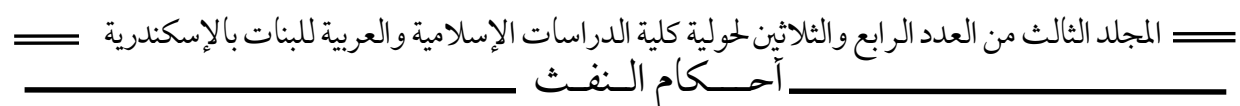

المبحث الثالث : النفث في العسل والزيت وغيرهما من الدهونات.

المبحث الرابع : بيع ما نفث علية بالرقية الشرعية من ماء وزيت وعسل وغيرهم.

المبحث الخامس: النفث في الصلاة ، وفيه مطلبان.

المطلب الأول: النفث في الصلاة للمنفرد.

المطلب الثاني : النفث في صلاة الجماعة.

المبحث السادس : النفث عند رؤية ما يكره في المنام.

الخاتمة 


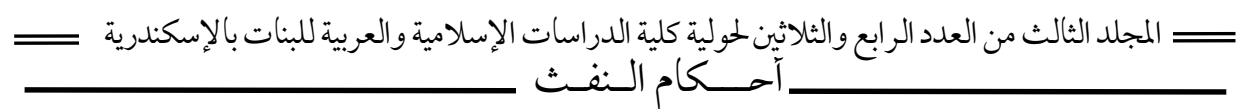

التمهيد: في تعريف النفث والألفاظ ذات الصلة و فيه ثلاثة مطالب: المطلب الأول: تعريف النفث وفيه ثلاثة مسائل. المسألة الأول: تعريف النفث في اللغة. النفث : إخراج الريح من الفم من غير خروج شيء من الريق ، يقال: نَفَثَ ينفثث وينفُث، نفثاً و ونفثاناً. والنفث: أقل من التفل لأن التفل لا يكون إلا معه شيء من الريق ، و النفث شبيه بالنفخ. وقيل النفث قذف الريق القليل وهو أقل من التفل ونفث الراقي ريقة : وهو أقل من التفل والساحرة تنفث : وهو النفخ دون التفل. والنفاثة : الشضية تبقى من المسواك في فيّ الرجل فينفثها (1).

المسألة الثانية : تعريف النفث في الاصطلاح: قال النووي: والنفث نفخ لطيف بلا ريق. وقال أبو عبيد:( يشترط في التفل ريق يسير، ولا يكون في النفث ريق أصلاً). قال أبو بكر الأنباري: قال اللغويون : تفسير نفث : نفخ نفخاً ليس معه ريق. (؛) قال الزخشري:(والنفث بالفم شبيه بالنفخ ، ويقال نفث الراقي ريقه وهو أقل من التفل)(•).

(1) ينظر: لسان العرب 190/r ، تاج العروس من جواهر القاموس /

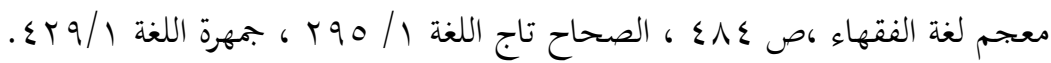

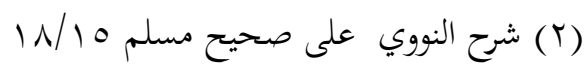

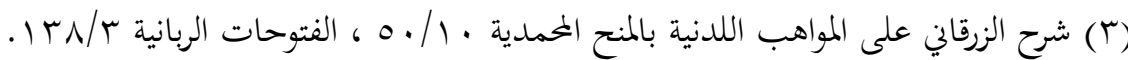

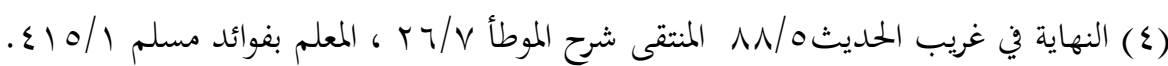

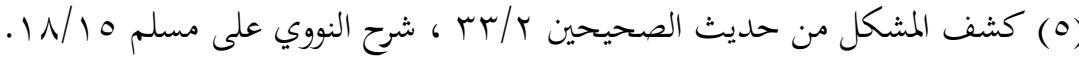


قال الحافظ: ( والصواب أن فيه ريقاً خفيفاً). (1)

عن أبي الحسن : النفث بغير بصاق كنافث عجم الزبيب والتفل بالبصاق. (r)

قال الشيخ محمد بن صالح العثيمين رحمه الله: النفث نفخ مع ريق خفيف. (ك) قال الشيخ عبد المحسن العبّاد : النفث ليس بصاقاً وإنما هو نفخ يسير. (ع) المسألة الثالثة: العلاقة بين المعنيين.

بالنظر إلى التعريف اللغوي للنفث والتعريف الاصطلاحي بند أن التعريف الاصطلاحي لا يكاد يخرج عن التعريف اللغوي فهو يدور حول النفخ بلا ريق أو بريق خفيف كما ذكر ذلك عدد من الفقهاء.

قال الشيخ صالح آل الشيخ: والرقية إما أن تكون بنفث أو بتفل أو بما هو دون هذين ، هذا إذا اختلف العلماء في مسألة هل تشرع الرقية بنفخ دون نفث ؟ على قولين ورُجح أن الجميع جائز ، فإن كان بنفخ وهو مالا ليس معه شيء من الريق، وإنما هو اخراج هواء فقط فهو جائز ، وإن كان بنفث فهذا هو المشروع والذي كان عليه الصلاة والسلام يقرأ ويتعوذ وينفث في يديه وينفث على المريض أيضا ، وإما أن تكون بما هو أعظم من النفث وهو التفل ، والنفث إخراج بعض الريق ، قليل من الريق مع الهواء يعني إذا أراد أن ينفث ، يقرأ الفاتحة وإذا ختم ينفث مع بعض الريق أو يتفل (•).

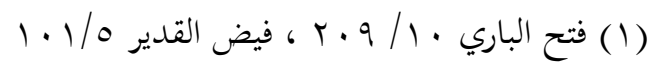

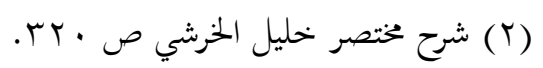

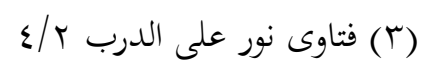

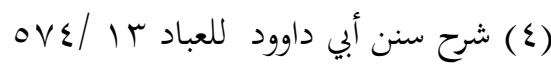

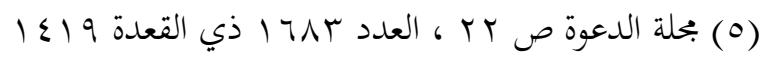


المطلب الثاني : الألفاظ ذات الصلة:

1. التفل :شبيه بالبزاق وهو اقل منه (1)

قال ابن الأثير: ( التفل شبيه بالبزاق وهو اقل منه) (r)

r. البصاق: ماء الفم إذا خرج منه. يقال: بصق يبصق بصاقاً ، ويقال فيه

أيضًا : البزاق، والبساق. وهو بالصاد افصح (r)

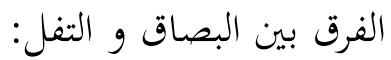

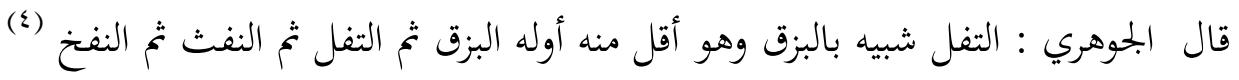

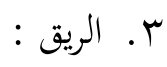

الريق هو : ماء الفم (لعابه) ما دام فيه وجمعه أرياق ، ورياق ، ويقال له الرضاب (o)

ه. (7) اللعاب : ما يسيل من الفم.

المطلب الثالث: صفة النفث

وقد وصفت أم المؤمنين عائشة_ رضي الله عنها _ـ نفث النبي صلى الله عليه وسلم : عن عبيد الله بن عبدالله قال سألت عائشة فقلت : أي أمه اخبريني عن مرض رَسُولُ اللَّهِ صَلَّى اللَّهُ عَلَيْهِه وَسَلَّمَ ، قالت اشتكى فعلق ينفث فجعلنا نشبه نفثه بنفثة آكل الزبيب (V)

$$
\begin{aligned}
& \text { (1) القاموس المحيط ؟0 1 1 }
\end{aligned}
$$

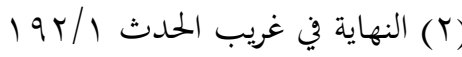

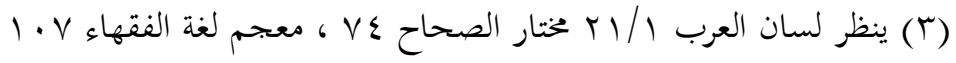

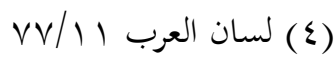

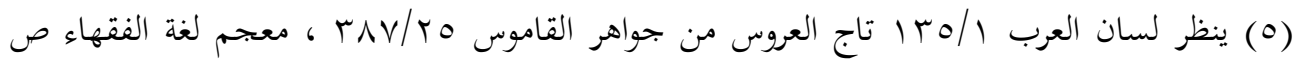

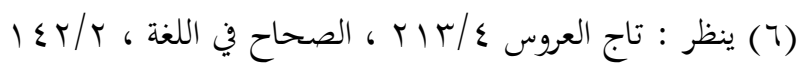

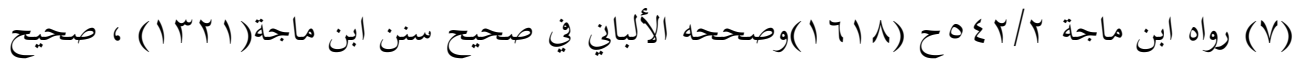

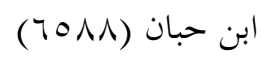




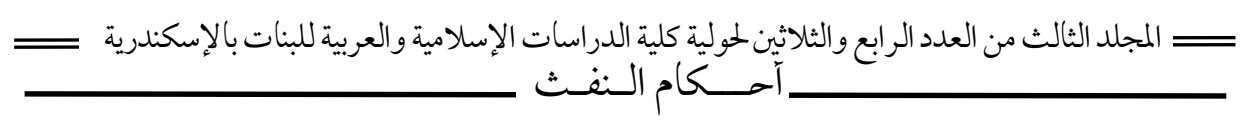

ونافث الزبيب لا بزاق معه ولا اعتبار بما يخرج عليه من بله ولا يقصد ذلك (1) وهذا ما يتفق مع ما سبق ذكره في التعريف من أنه نفخ بدون ريق ، أو مع ريق قليل قد يخزج بدون قصد من النافث.

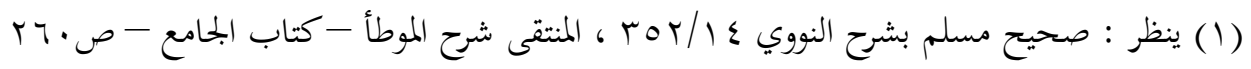




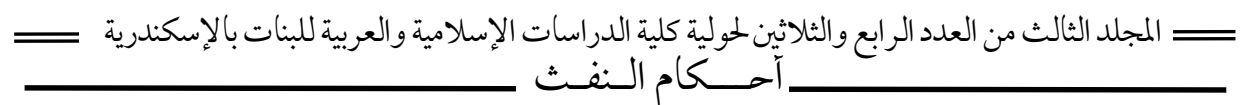

\section{المجحث الأول}

\section{النفث على الجسل}

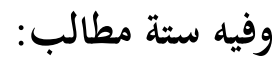

المطلب الأول: نفث الإنسان في كفية ومسح الجحسد عند النوم.

ثبت عن النبي _ صلى الله عليه وسلم _ أنه كان ينفث على نفسه بالمعوذتين والإخلاص

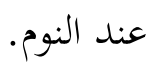

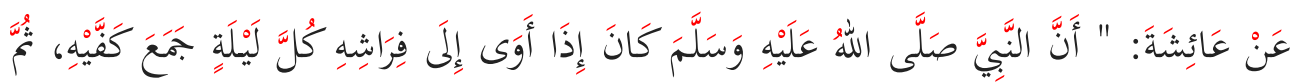

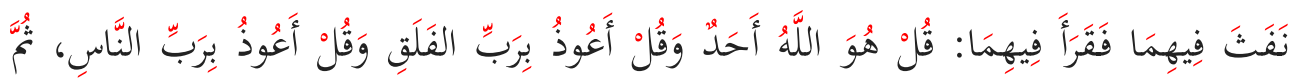

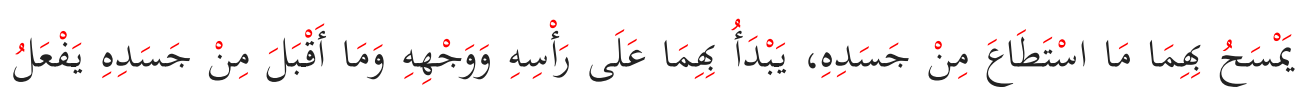

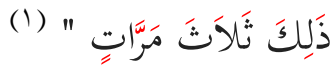
فهذا حديث صحيح في استحباب قراءة المعوذتين وسورة الإخلاص والنفث في الكفين والمسح على ما يستطيعه من جسده ثلاثاً عن النوم. وفيه جواز الاسترقاء للصحيح لما عساه يخشاه من طوارق الليل وهوامه وغير ذلك مما يسترقى له ، فيمنعه الله من أذى ذلك. وفي الحديث مسائل: (n) المسألة الأولى: ما الذي يمسح من البدن؟

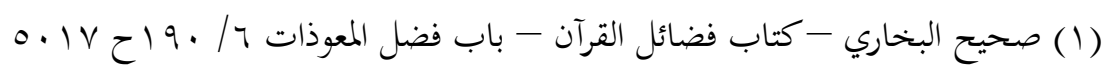

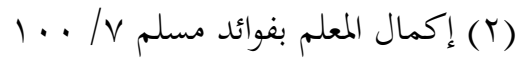


قال الشيخ عبد المحسن _العباد حفظه الله_: أما المراد من قوله : (ثم يمسح بهما ما استطاع من جسده) يعني : الذي يمكنه من جسده ، لأن بعض المواضع من الجسد لا لا تصل إليها (1) اليد. (1)

قال الشيخ محمد بن صالح العثيمين رحمه الله ( فينبغي للإنسان إذا أخحذ مضجعه أن يفعل

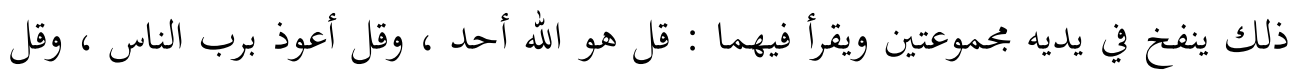

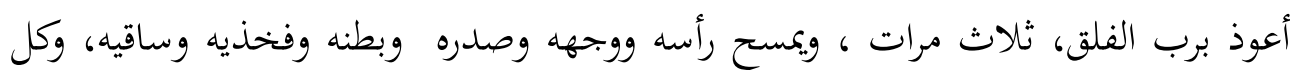
ما يستطيع من جسده ). (r)

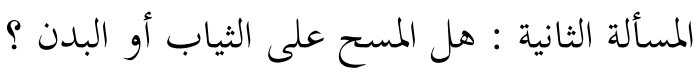

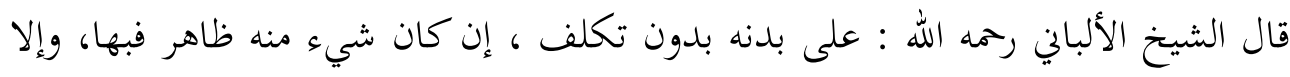
على ثيابه. المسألة الثالثة : كم عدد مرات المسح و القراءة والنفث ؟

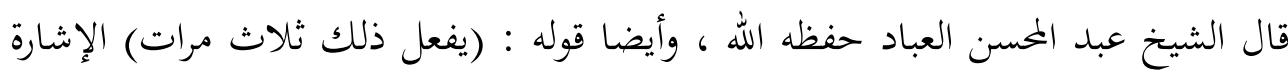
تعود إلى المسح بعد النفث ثلاث مرات وعلى القراءة ، يعني: أنه يكرها ويمسح

المطلب الثاني : حكم النفث في الرقية. اختلف العلماء في مشروعية النفث في الرقية على قولين. القول الأول: مشروعية النفث في الرقية ، وهو قول الجماهير من أهل العلم.

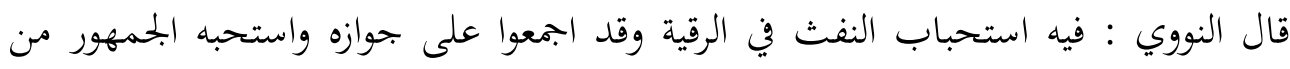

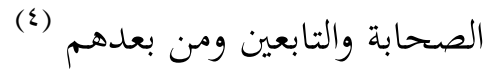
وبوّب البخاري في صحيحه ( باب النفث في الرقية). (o)

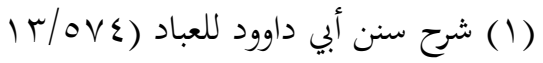

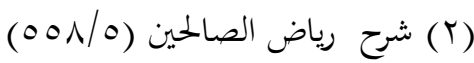

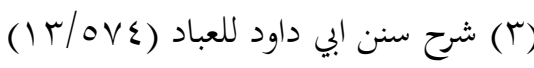

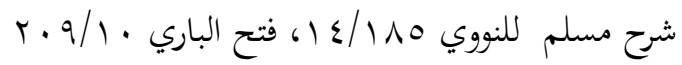

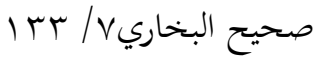


قال ابن عبد البر: وفيه إثبات الرقى ، والرد على من أنكره من أهل الإسلام وفيه الرقى

بالقران ، ووفي معناه كل ذكر لله جائز الرقية به ، وفيه إباحة النفث في الرقى والتبرك به (1)

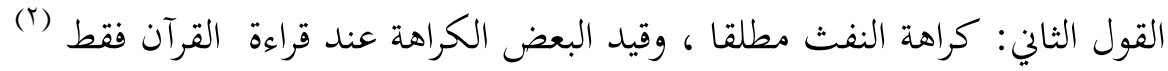

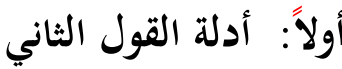

استدل من قال بكراهية النفث بقوله تعالى : (ومن شر النفاثات في العقد) سورة الفلق : ع وجه الاستدلال من الآية: - n أن الله عز وجل أمر بالاستعاذة من النفث ومن فاعله. الجواب على هذا الاستدلال: - ال

قال ابن بطال : (ليس في ذمه عز وجل نفث أهل الباطل ما يوجب أن يكون كل نافث ونافثة للحق في معناه ، لأن النفاثات التي أمر الله تعالى نبيه بالاستعاذة من شرهن السحرة ، أما من نفث بالقرآن وبذكر الله تعالى على النحو الذي كان صلى الله عليه وسلم وأصحابه ينفثون فليس مما أمر الله تعالى بالاستعاذة من شره ، وقد صح عن النبي صلى الله عليه وسلم أنه نفث على نفسه بالمعوذات وأقر الصحابي الذي تفل على اللديغ بالفاتحة. (r)

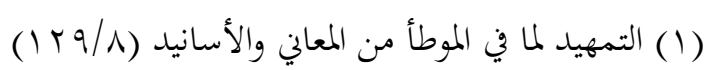

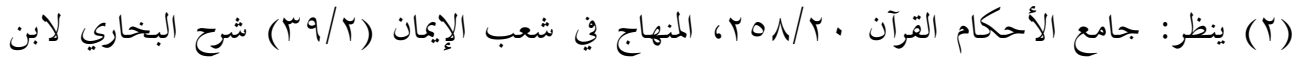

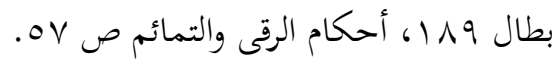

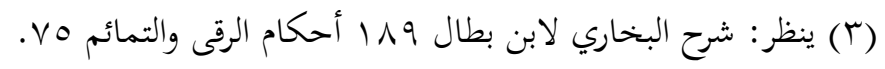


وقال ابن حجر: (أما من كره النفث عند قراءة القرآن خاصة كإبراهيم النخعي فالحجة عليه

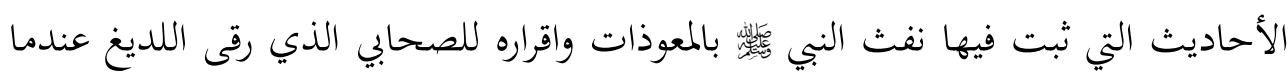
كان يتفل في الرقية (1) وقال الأستاذ عكاشة عبد المنان الطيبي:( وأما ما روى عن عكرمة من قوله: لا ينبغي للراقي ان ينفث ، فكأنه ذهب فيه إلى أن الله تعالى جعل النفث في العقد مئا يستعاذ به ، فلا فلا

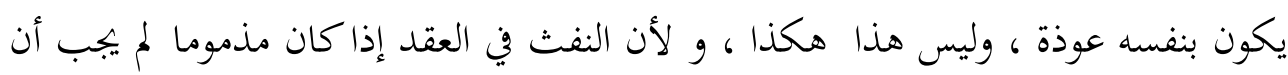

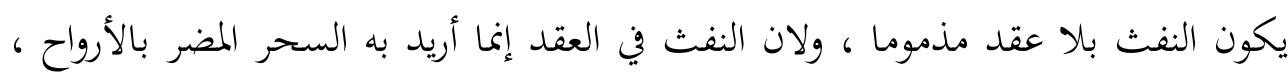
وهذا النفث لاستصلاح الأبدان فلا يقاس ما ينفع بما يضر وأما كراهة عكرمة المستح فخلاف السنة (r).

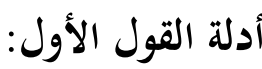
استدل من قال باستحباب النفث في الرقية بأدلة :

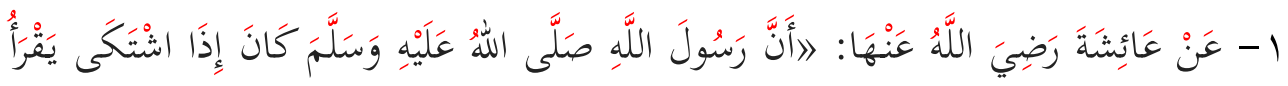

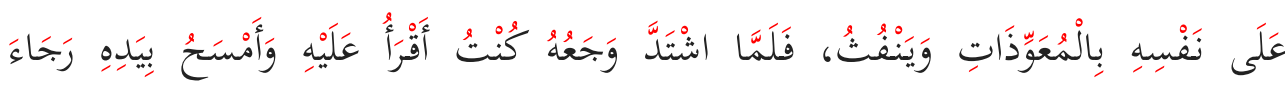

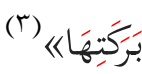

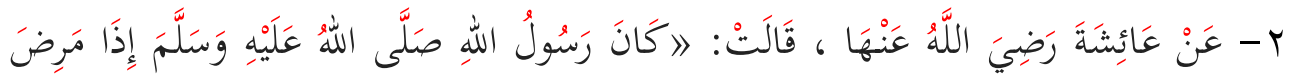

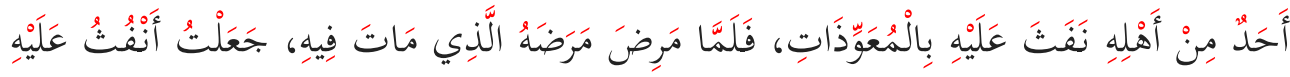

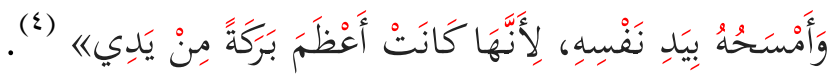

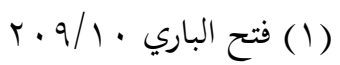

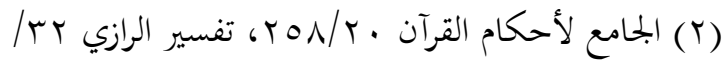

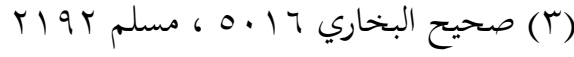

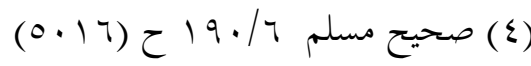




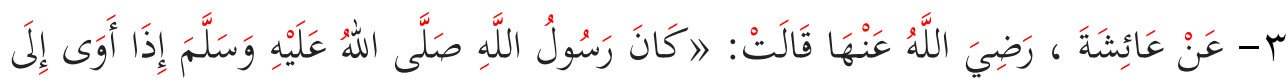

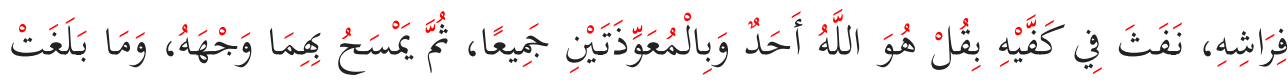

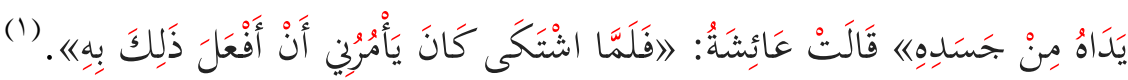

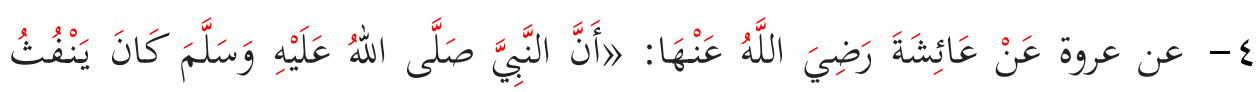

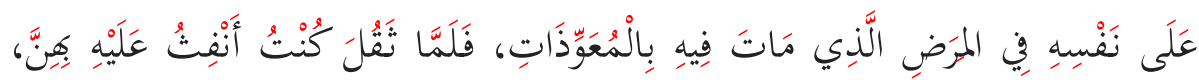

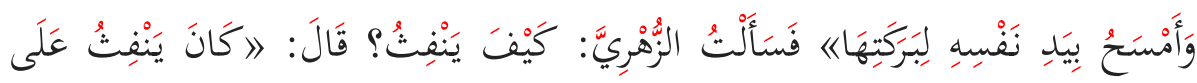

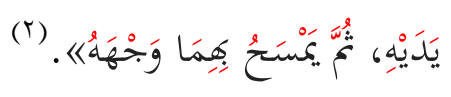

ع - عن محمد بن حاطب أنه احترقت يده فانطلقت به أمه إلى رَسُولُ اللَّهِ صَلَّلى اللَّهُ عَلَيْهِ

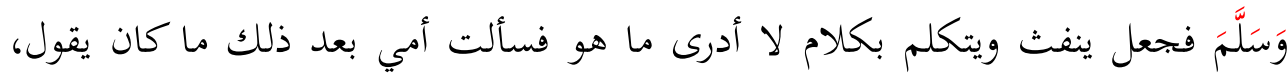

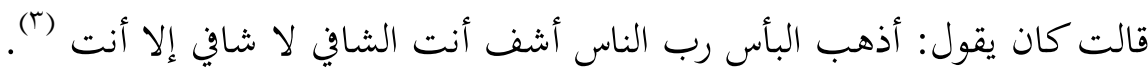

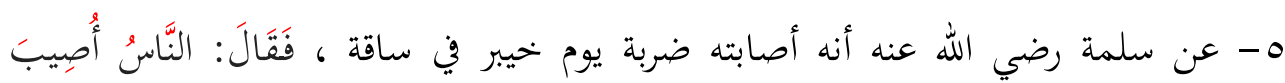

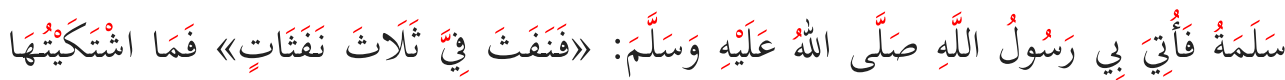

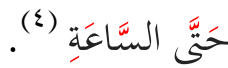

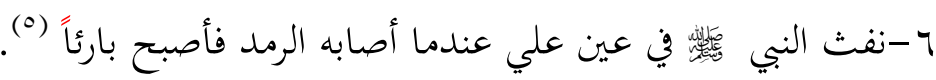

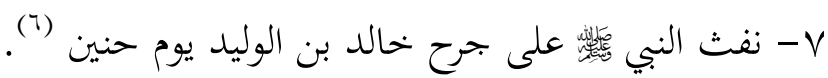

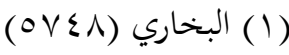

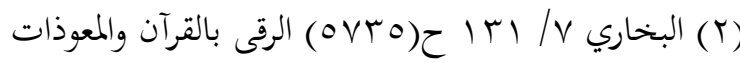

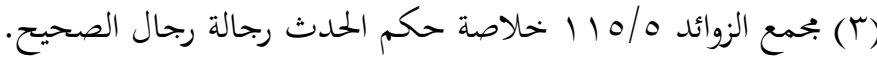

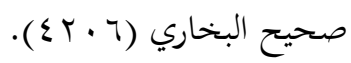

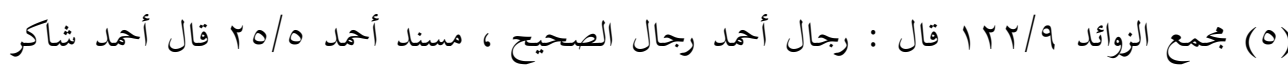
اسناده صحيح

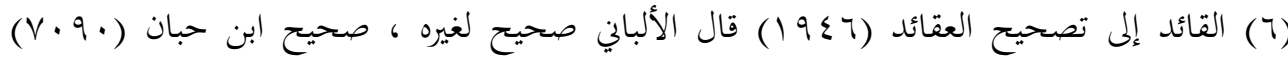

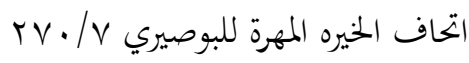


بالنظر إلى الأدلة السابقة يترجح لي القول بجواز النفث في الرقية لقوة أدلتهم وسلامتها من المعارضة ، وأخذًا لعموم الاستشفاء بالقرآن الكريم، لأن الله أخبر أنه شفاء فلا بأس به -

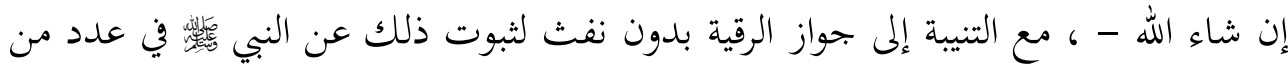
الأحاديث والله أعلم. المطلب الثالث : هل النفث قبل القراءة أو بعدها؟ أختلف العلماء في ذلك على ثلاثة أقوال : الأول: أن النفث يكون قبل القراءة. الثاني : أن النفث يكون بعد القراءة. الثالث: أن النفث يكون حال القراءة أو معها.

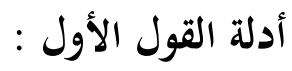

ا - عن عائشة _رضي الله عنها _قالت:( كان رَسُولُ اللَّهِ صَلَّى اللَّهُ عَلَيْهِه وَسَلَّمَ إذا

أوى إلى فراشه كل ليلة جمع كفية ثم نفث فيها وقرأ (قل هو الله أحد) و (قل سل

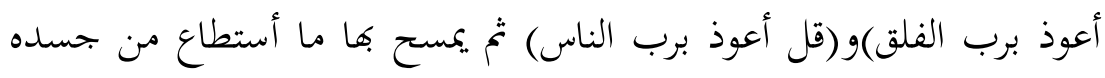

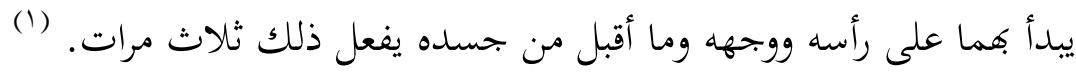

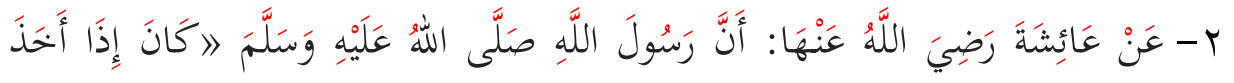

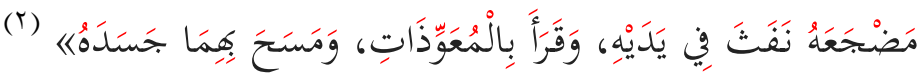

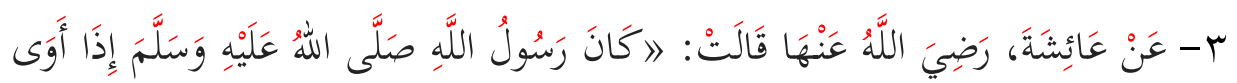

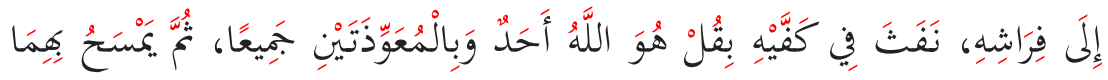

$$
\text { (1) (1) (1) صحيح البخاري سبق تخريجه }
$$

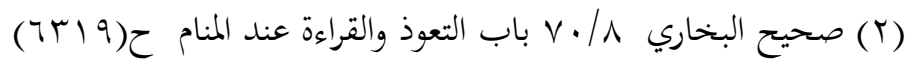




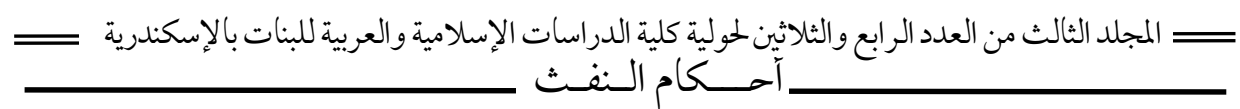

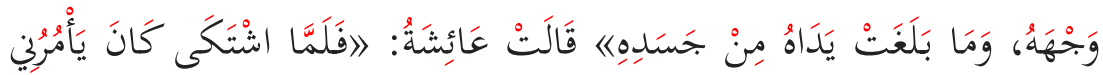

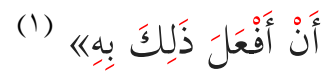

مناقشة هذا الاستدلال:

ذُكر النفث بالقراءة فلا يكون النفث إلا بعد القراءة ، وإذا فعل الشيء لشيء كان

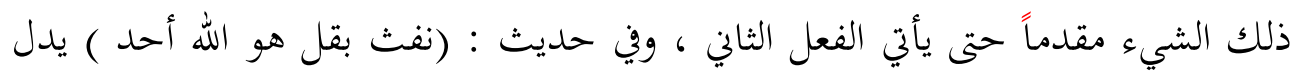

على أن لقراءة تقدم ثم نفث ببركتها.

الجواب:

ظاهر الحديث يدل على أنه نفث في كفه أولاً: وذكر الطيبي أنه قد يكون السر في تقديم

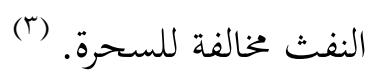

أدلة القول الثاني:

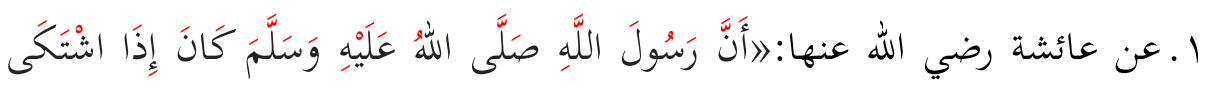

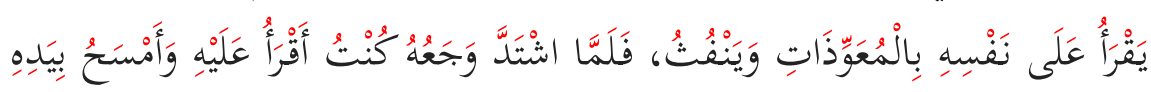

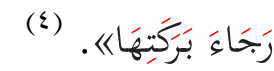

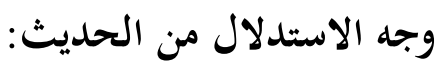

أنه يقرأ أولاً ثم ينفث ، ليوصل بركة القرآن إلى بشرة القارئ أو المقروء له (') ، قال

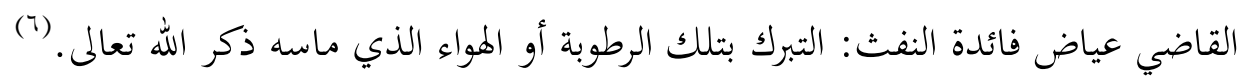

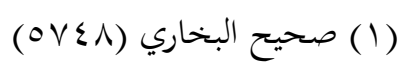

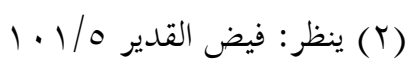

$$
\begin{aligned}
& \text { (T) }
\end{aligned}
$$

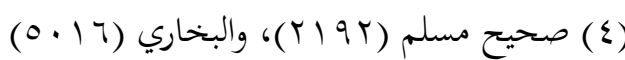

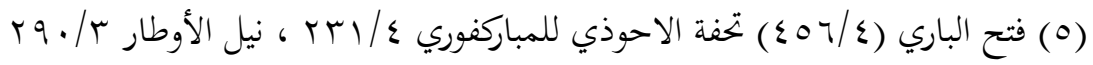

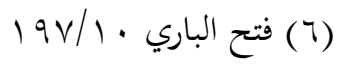




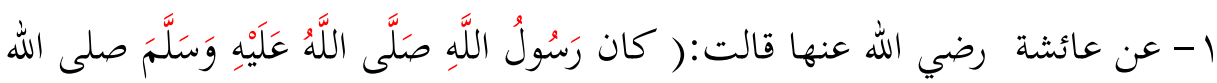
عليه وسلم إذا أوى إلى فراشه نفث في كفية بـ ( قل هو الله أحد و المعوذتين جميعا...) (1) قال الحافظ ابن حجر قوله : ( نفث في كفيه بقل هو الله أحد.....

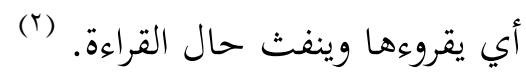

جاءت الروايات الصحيحة بالنفث أولاً ثم القراءة ، وبالقراءة أولاً ثم النفث ، والأمر في ذلك واسع إن شاء الله ، فأيهما فعل حصل المطلوب كما ذكر ذلك الشيخ ابن عثيميين رمه الله (ॅ) تعالى.

المطلب الرابع : النفث بالمعوذتين والمسح بعد كل صلاة.

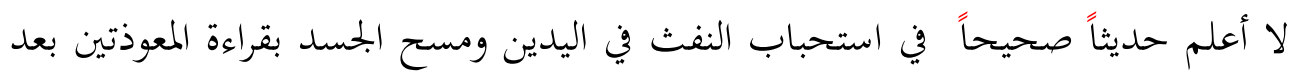

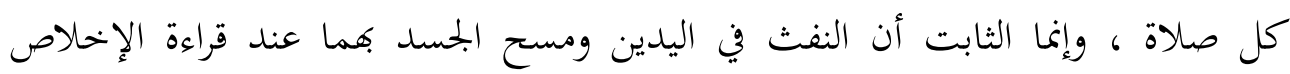

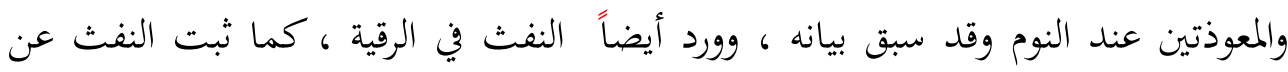

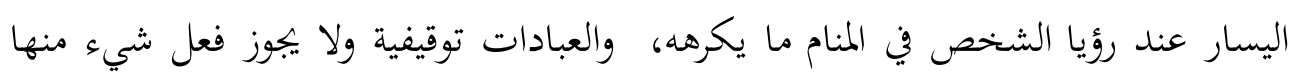

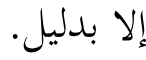

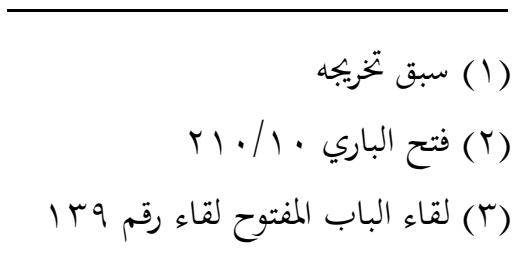


المطلب الخامس : النفث في الكفين والمسح عند قراءة أذكار الصباح والمساء. لم يثبت حديث صحيح في النفث بأذكار الصباح والمساء بخصوصها ، وإنما الثابت أن النفث في اليدين ومسح الجسد بها عند قراءة الإخلاص والمعوذتين عند النوم ، وقد قاس بعض أهل العلم تلاوة القرآن والأذكار المشروعة عليها فقالوا : إذا كان النفث مشروعاً في هذا الموضع ، يكون مشروعاً في غيره قياساً عليه ، ولكن الصحيح أنه ما لم يرد له دليل في الكتاب ولا في السنة لا يشرع التزامه.

المطلب السادس: النفث عن طريق الهاتف أو الجوال أو التلفاز وغيرهم من وسائل

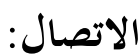
قد يتعذر على المريض الذهاب إلى الراقي ، فهل يمكنه الانتفاع بالرقية والنفث عبر الهاتف أو الجوال أو التلفاز ، و غيرها من برامج التواصل الحديثة ، التي تتيح الاتصال بالصوت والصورة.

تحدث العلماء في العصر الحديث عن الرقية عن طريق هذه الوسائل وانقسموا إلى قولين القول الأول: أن الرقية بالهاتف أو الجوال وغيره ما من وسائل التواصل لا تعد رقية شرعية ، لأن ذلك يخالف ما ورد عن الرسول ئس يقتضى المباشرة مع المريض كي ينتفع بالنفث الذي خالطه ذكر الله والأدعية النبوية (1). القول الثاني : جواز الرقية بالجوال والتلفاز والهاتف وغيرهم من وسائل التواصل اذا وجدت النية من الراقي والمسترقي ، وأن صوت النفث مؤثر في الرقية بهذه الوسائل وجرب ونفع. (r)

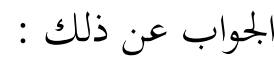

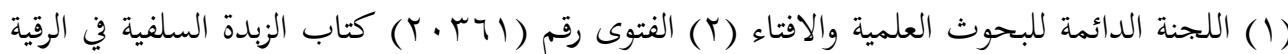

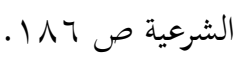
(r) قال بذلك الشيخ عبد العزيز الفوزان ، في فتوى له مرئية على اليوتيوب على الشبكة العنكبوتية. 


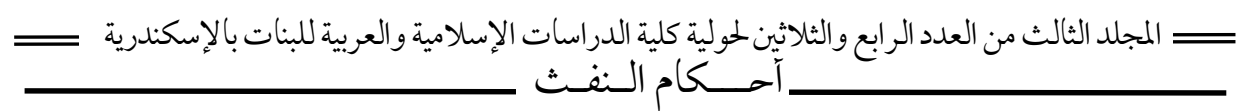

أن القرآن شفاء وكون الإنسان يتأثر بسماع الرقية فاستماع القرآن بتدبر وخشوع وتعلق ويقين بالله عز وجل نافع ، ولكن الرقية بالنفث متعذرة بهذه الطريقة ، لأن الفائدة من النفث هي التبرك بالنفس والريق الذي خحالطه ذكر الله عز وجل ، فالرقية بالهاتف أو الجوال

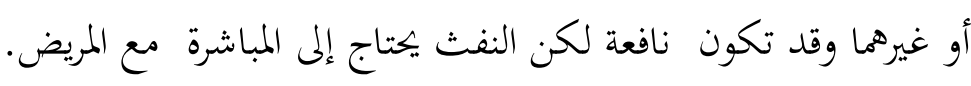

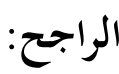

ترجح لي أن النفث عن طريق التلفاز والهاتف أو الجوال أو غيرهم من وسائل التواصل من التوسع في أمر الرقية ، والأصل أن الرقية ليست محصورة في اشخاص معينين ولكن تعلق الناس ببعض الرقاه هو الذي دفعه إلى ذلك ، فلو رقي الإنسان نفسه أو طلب الرقية من حوله أولى من الرقية بالهاتف أو الجوال أو غيرها من وسائل التواصل المباشر. 


\section{المبثث الثازي}

\section{تأثن}

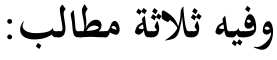

المطلب الأول: النفث في الماء بالرقية الشرعية وشربه والاغتسال به. اختلف العلماء وفي ذلك على قولين. القول الأول: عدم جواز النفث بالرقية في الماء. وممن قال بذلك الشيخ محمد ناصر الدين

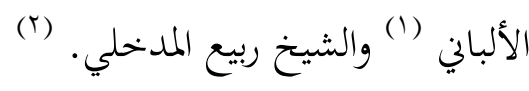
القول الثاني : جواز النفث بالرقية في الماء وشربه والاغتسال به وقال بذلك كثير من العليه

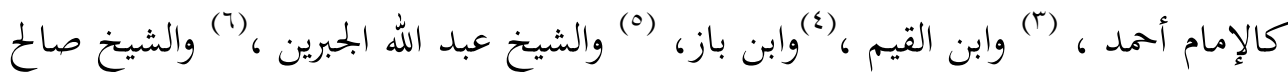

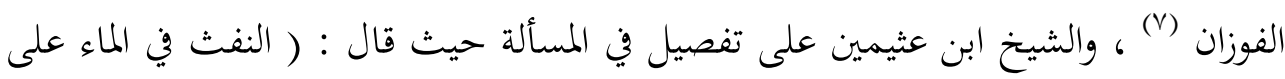

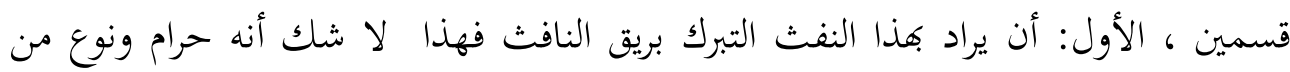
الشرك. لأن ريق الإنسان ليس سببا للبركة والشفاء ولا أحد يتبرك بآثاره إلا محمد عليه الصلاة والسلام أما غيره فلا يتبرك بآثاره.

$$
\begin{aligned}
& \text { (1) موقع الشيخ الألباني فتاوى الشيخ رقم الشريط rلVه رقم الفتوى } 9 \text { وشريط مدـ رقم الفتوى } \\
& \text { (Y) (ب) موقع الشيخ ربيع المدخلي }
\end{aligned}
$$

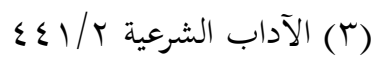

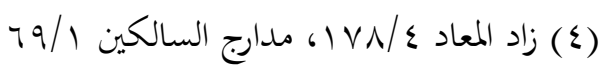

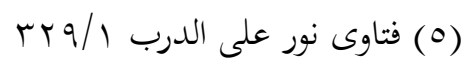

$$
\begin{aligned}
& \text { (7) (7) موقع الشيخ على الشبكة العنكبوتية. } \\
& \text { VY/l المنتقى (V) }
\end{aligned}
$$


والقسم الثاني : أن ينفث الإنسان بريق تلا فيه القرآن فيقرأ وينفث في الماء فإن هذا لابأس

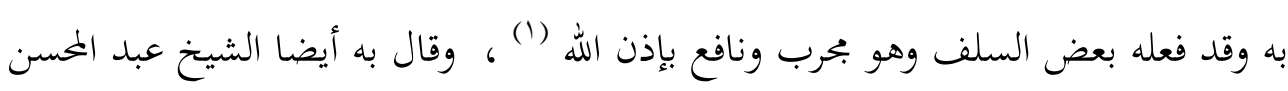
(「) العبّاد

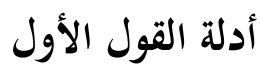

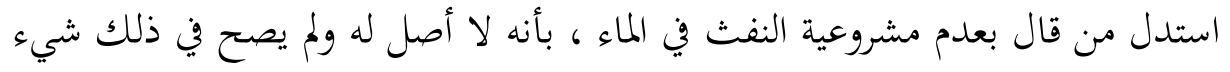

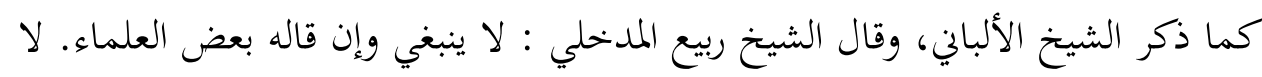

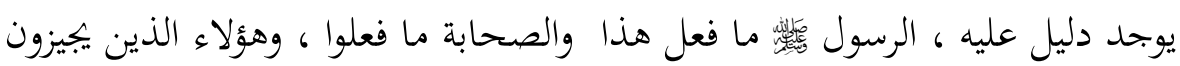

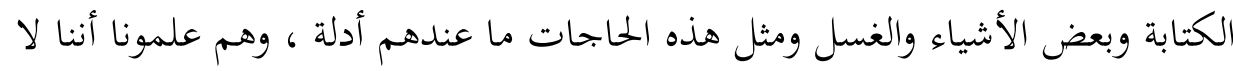

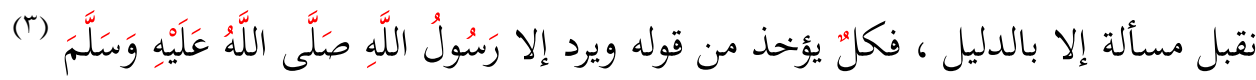

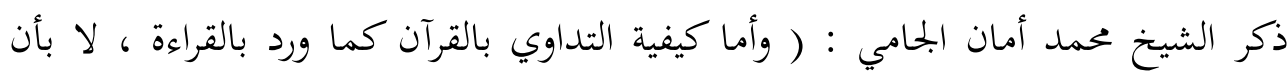

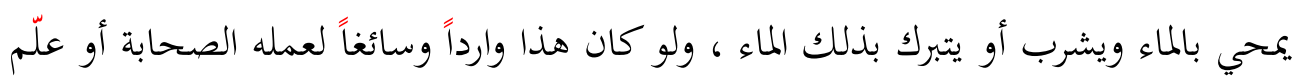

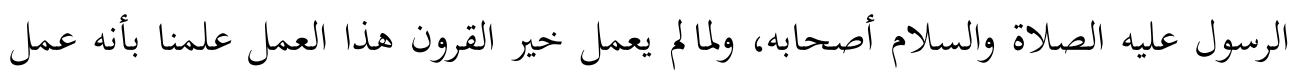

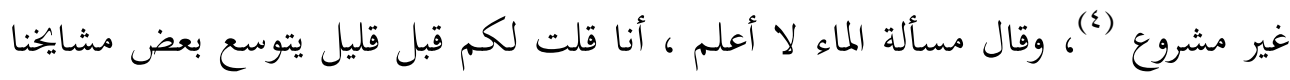

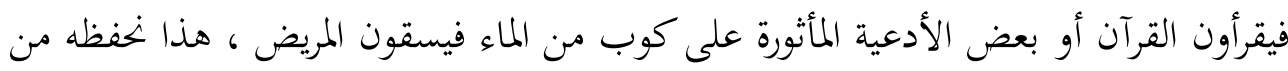

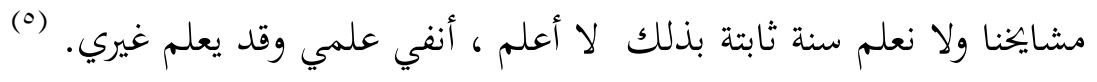

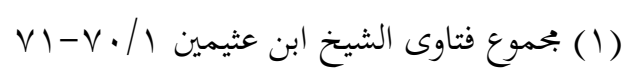

$$
\begin{aligned}
& \text { شا }
\end{aligned}
$$

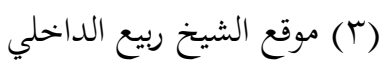

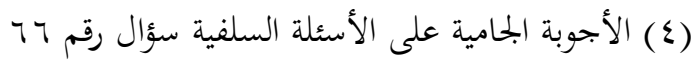

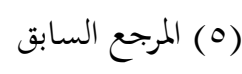




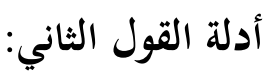

استدل من قال بمشروعية الرقية في الماء بأدلة :

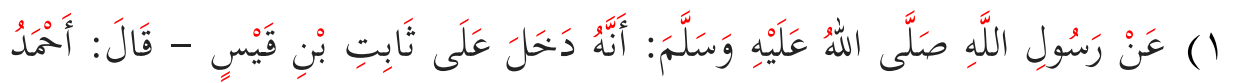

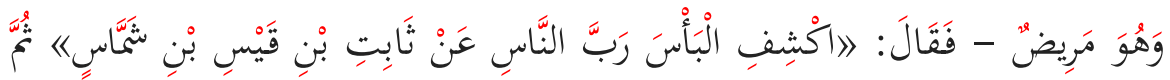

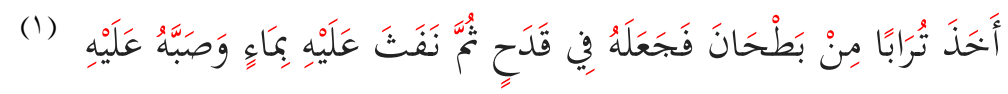

\section{مناقشة الاستدلال}

الحديث في اسناده ضعيف.

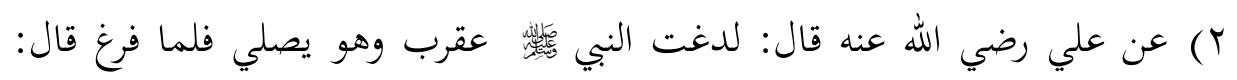
لعن الله العقرب، لا تدع مصليا ولا غيره و ثم دعا بماء وملح وجعل يمسح عليها ويقرأ بـ ( قل يا أيها الكافرون ) (وقل أعوذ برب الفلق) وقال أعوذ برب الناس (r) وفي رواية : ( ثم دعا بماء وملح ، فجعله في إناء ثم جعل يصبه على اصبعه حيث

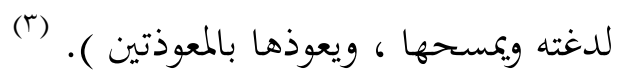
مناقشة الاستدلال بهذا الدليل: أنه عليه الصلاة والسلام استعمل الملح مع الماء لنفعه في دفع السموم، ولا سيما لدغة العقرب كما ذكر ذلك الأطباء ، قال صاحب القانون: يضمد بـه مع بزر الكتان للسع العقرب (ع) . وذكروا أيضاً أن في الملح من القوة الجحاذبة المحللة ما يجذب السموم ويحللها () ،

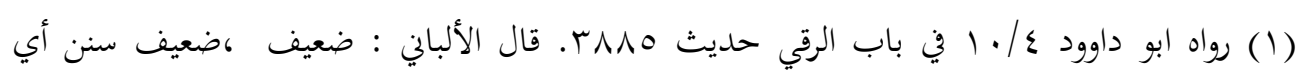
داوود

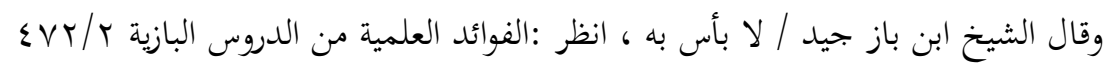

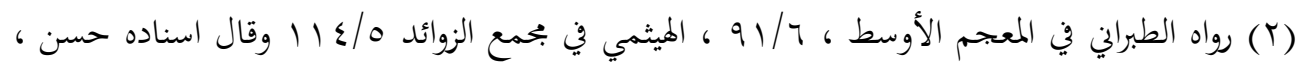
والألباني في السلسلة الصحيحة رقم 1 ــه

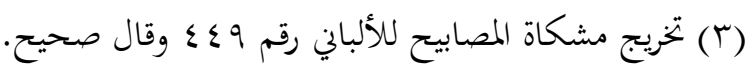

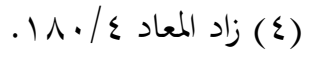

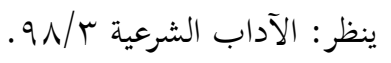


فالنبي عليه الصلاة والسلام جمع بين العلاج الآلهي والعلاج الطبيعي وهو الماء والملح لعلاج

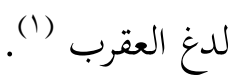
وليس في الحديث ذكر للنفث في الماء وشربه.

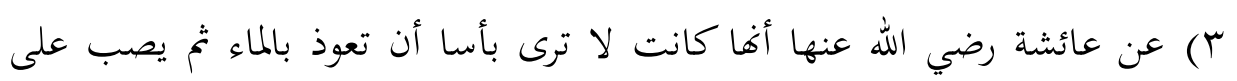

$$
\text { المريض (r) (ب) }
$$

ع) ورد عن كثير من السلف أهم كانوا يرون مشروعية النفث في الماء ومن الأمثلة على ذلك : ما ذكره صالح ابن الإمام أحمد بن حنبل رحمه الله قال: ربما اعتللت فيأخذ أبي قدحا فيه ماء فيقرأ عليه ويقول لي اشرب منه وأغسل وجهك ويديك ونُقل عن ابنه عبد الله أنه رأى أباه يعوذ في الماء ويقرأ عليه ويشربه ، ويصب على نفسه منه

$$
\text { (r) (َ) وذكر ذلك ابن القيم وغيره }
$$

$$
\text { الترجيح }
$$

يترجح عندي _ والله أعلم _ جواز النفث في الماء بالرقية الشرعية لفعل السلف لذلك. وأرى أن الأفضل والأكمل أن يقرأ الإنسان بنفسه وينفث هو في الماء ،

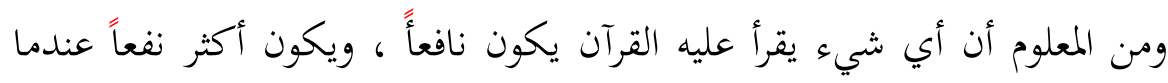

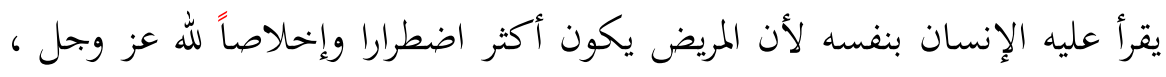

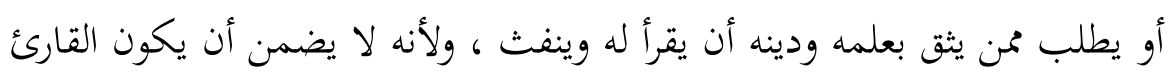

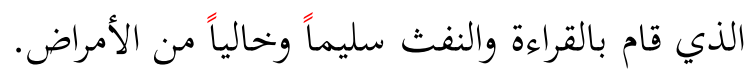

$$
\begin{aligned}
& \text { (1) ينظر: التداوي بلا دواء د. أمين رويحة ص بrا ا. }
\end{aligned}
$$

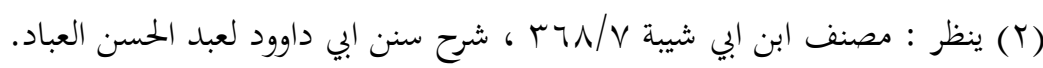

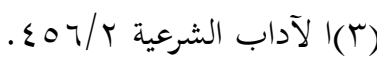

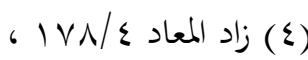


المطلب الثاني:الجمع بين أحاديث النهي عن النفخ في الماء ، وبين من يرى جواز النفث فيه.

ورد عن النبي أس النهي عن التنفس و النفخ في الشراب فقال عليه الصلاة والسلام: ( إذا

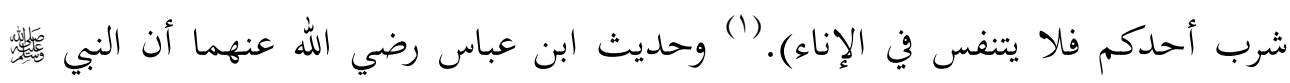

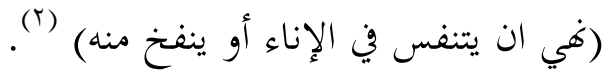

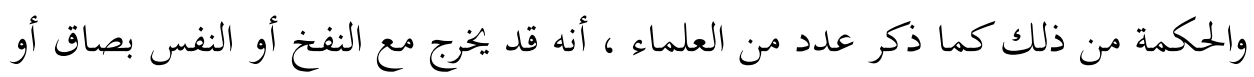
بخار رديء فيكسبه رائحة كريهة ، سواء شاركه أحد في الإناء أو لم يشاركه (").

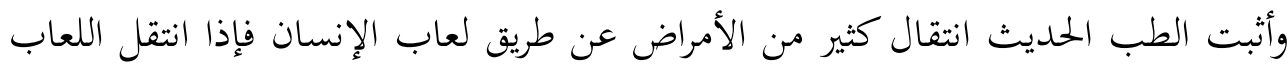

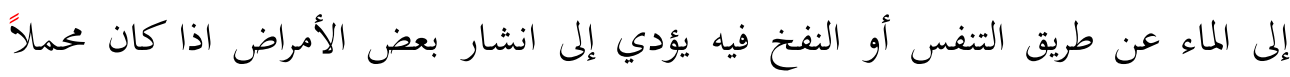

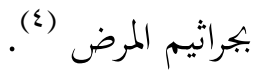
فالنهي عن النفخ في الطعام ثابت في الأحاديث وعلة النهي تقذيره على الناس ، وهذا

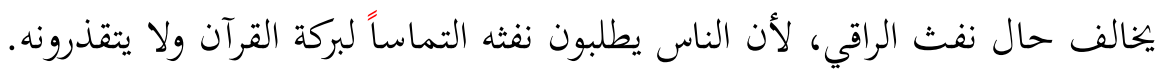

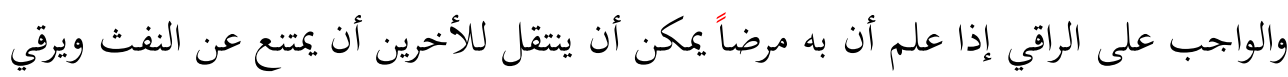

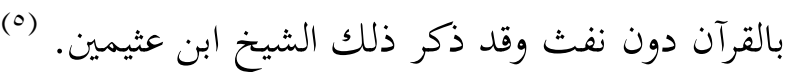

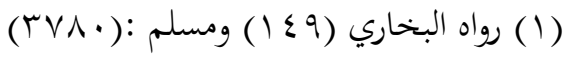

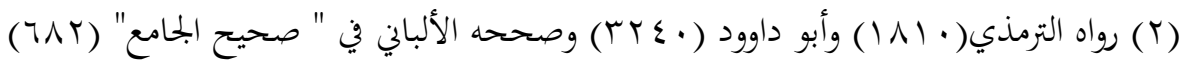

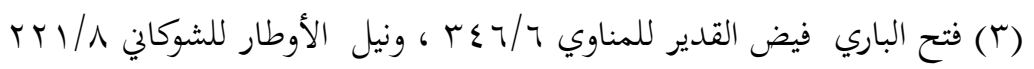

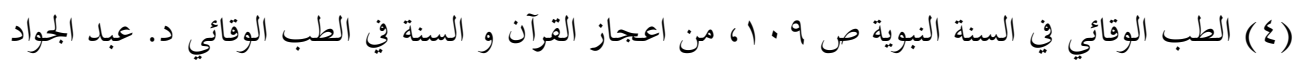

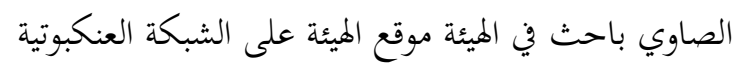

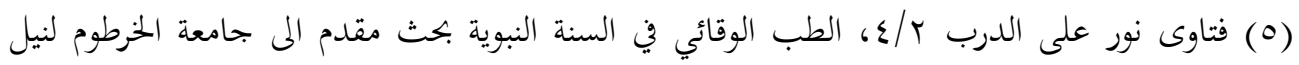
ماجستير الأداب في الدراسات الإسلامية إعداد/ هند بابكر سليمان، جامعة الخرطوم ، 1999 
المطلب الثالث: الوضوء و الاغتسال بالماء الذي نفث فيه بالرقية الشرعية في دورات

المياه.

للعلماء في ذلك قولان:

الأول: كراهية الاغتسال به وقدر روي ذلك عن الإمام أحمد (1) ، والشيخ عبد الله جبرين (r) . وابن عثيمين (r). (يرى جواز المسح فقط).

الثاني: جواز ذلك ما لم يتعمد الإهانة بعينها ، وقال به عدد كبير من العلماء في العصر

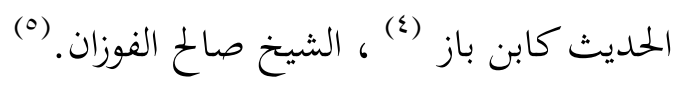
الادلة:

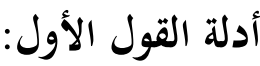

قالوا فيه منافاة للأدب والتعظيم لله عز وجل ، لأن العادة أن الغسل يجري في المجاري الملوثة بالنجاسات ، فوجب أن ينزه القرآن عن ذلك (7). سئل فضيلة الشيخ عبدالله بن عبدالرحمن الجبرين عن حكم الاستحمام بالماء المقروء عليه في أماكن الخلاء فأجاب - رحمه الله - : ( نرى احترام هذا الماء الذي قد قرأ فيه أحد الناصحين ونفث فيه بآيات من كتاب الله تعالى ، كآية الكرسي وخواتيم سورة البقرة وآخر سورة الحشر والفاتحة والمعوذتين وسورتي الإخلاص ونخوها ، فهذا الماء اكتسب شرفا وأثرا حسنا ، فمن احترام كالام الله تعالى أن لا يهراق مع النجاسات والاقذار ، وأن يستعمل في داخل الإنف

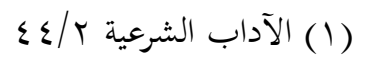

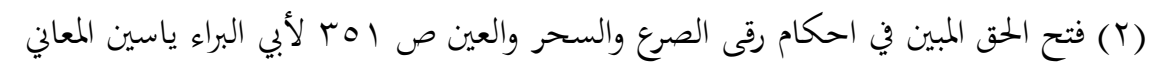

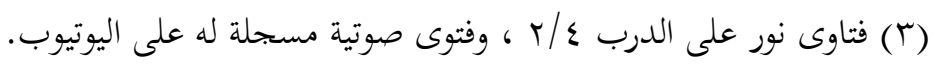

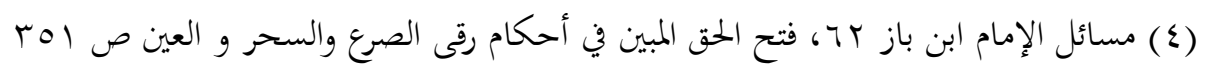

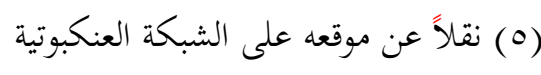

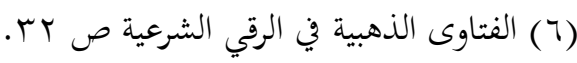


والمراحيض كما يدخل الكنيف بشيء فيه ذكر الله من أوراق وخاتم أو نحوها فعلى هذا إذا أراد أن يغتسل به فإن عليه أن يستعمله في مكان نظيف كغرفة أو خدر أو سطح أو

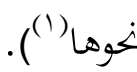

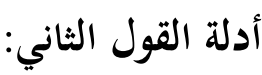

ا - قالوا: لا يوجد دليل على المنع والأصل الحل ، ولو كان ذلك لا يجوز أو فيه حرج

$$
\text { (r) }
$$

Y - أن هذا الماء المرقي فيه ليس فيه قرآن أبداً ، والذي علق بالماء هو الريق والنفث فقط، أما الآيات التي قرأها الراقي فهي خطاب ونداء وثناء على الله والتجاء ودعاء وتضرع بين يدي الله، فلم يحصل أي شيء من القرآن في الماء وليس فيه

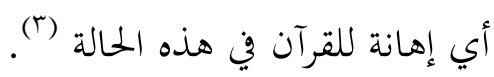

الترجيح: الذي يترجح لي والله اعلم جواز الوضوء والاغتسال بالماء الذي نفث فيه بالرقية الشرعية في دورات المياه ، لعدم وجود الدليل وعدم الدليل هو حجة على بقاء الأصل ، ولما في ذلك من تيسير وعدم حصول مشقة على المسلمين.

\section{المطلب الرابع : كمية الماء الذي ينفث فيه بالرقية الشرعية.}

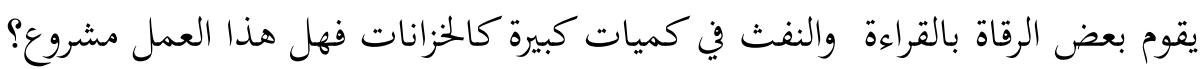

$$
\begin{aligned}
& \text { (1) فتح الحق المبين في احكام رقى الصرع والسحر والعين ص اهـ لأبي البراء ياسين المعاني } \\
& \text { (r) فتوى مرئية للشيخ خحالد المصلح على موقعة في الشبكة العنكبوتية. }
\end{aligned}
$$

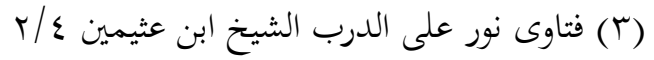


النفث في الماء كما رجحت سابقا أني لا أعلم فيه سنة عن رَسُولُ اللَّهِ صَلَّى اللَّهُ عَلْيْهِ وَسَلَّمَ

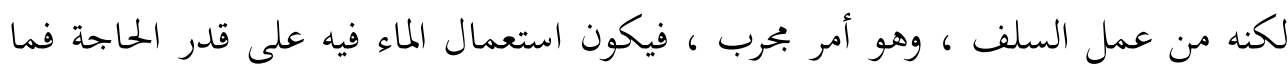

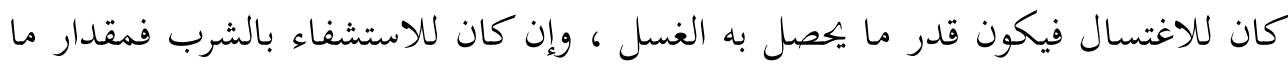

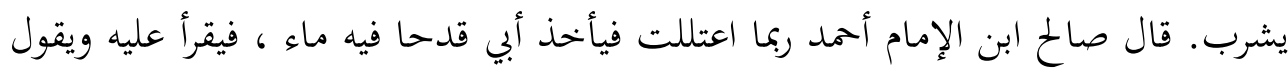

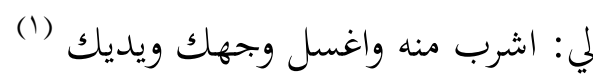
وقد سئلت اللجنة الدائمة للبحوث العلمية والافتاء عن الرقية في ماء ثم يفرغ ذلك الإناء في

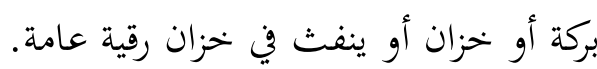

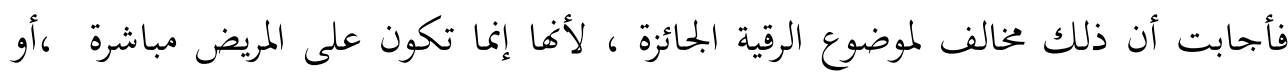

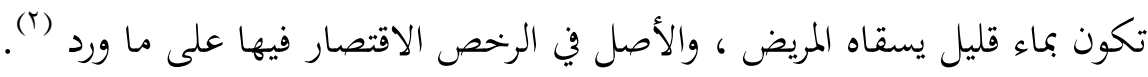

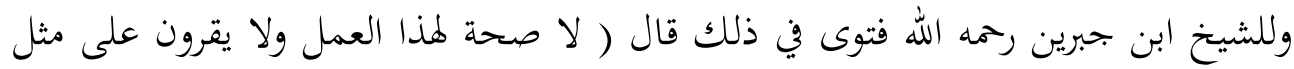
هذا العمل ، ولا تفيد هذه الرقية عادة...،ذكر أن الغالب فيمن يقوم بهذا العمل كسب المال والاحتيال على تحصيله بهذه الظواهر وهو محرم عليه. (") 


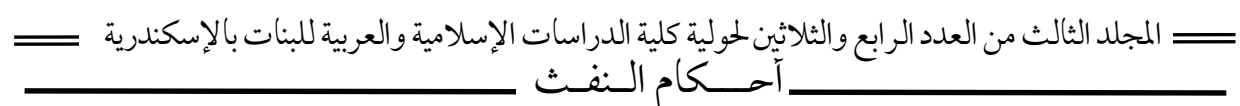

\section{المبحث الثالث}

\section{النفث فِّ العسل والزيت وغيره من الدهونات}

من يرى جواز النفث في الماء يرى جواز ذلك في الزيت والعسل والأدهان جميعها. واستدلوا على ذلك بقوله تعالى ( وننزل من القرآن ما هو شفاء ورحمة للمؤمنين ) الأسراء : Y وقد ذكر الشيخ ابن عثيمين جواز الرقية و النفث في جميع الأطعمة التي يأكلها المريض وفي

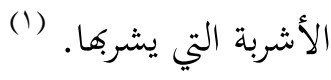

وقال : (فإذا استعمل القرآن على وجه ظهرت فيه الفائدة والمصلحة وليس فيه إهانة للقرآن الكريم فلا بأس، وقولنا ليس فيه إهانة للقرآن احترازاً مما يوجد في بعض الأواني يكتب في

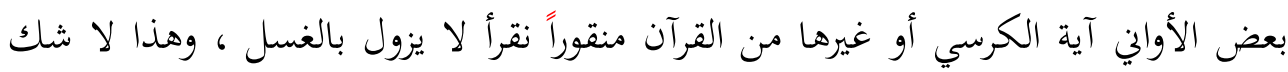

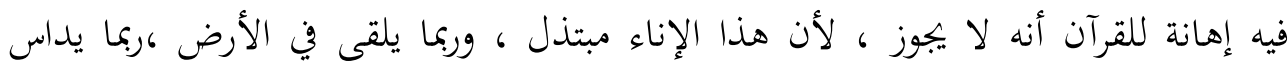
بالقدم.

$$
\text { (1 ) (1 ) بتاوى نور على الدرب ع/ المرجع السابق }
$$




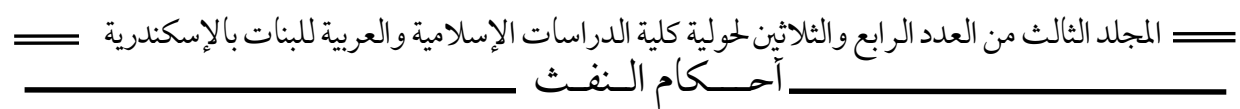

\section{المبحث الرابع}

\section{بيع ما نفث ملية بالرقية الشرعية من ماء وزيت وعسل}

\section{وغيرهم:}

$$
\begin{aligned}
& \text { اختلف العلماء في ذلك على قولين: } \\
& \text { الأول: جواز بيع ما نفث عليه بالرقية الشرعية. } \\
& \text { الثاني: عدم جواز بيع ما نفث عليه بالرقية الشرعية. }
\end{aligned}
$$

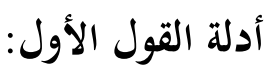

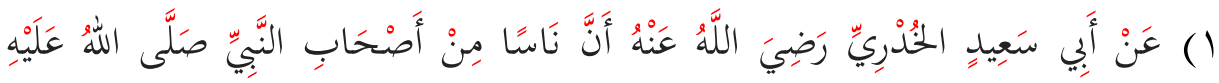

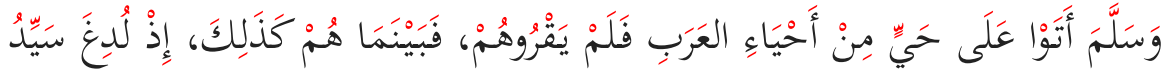

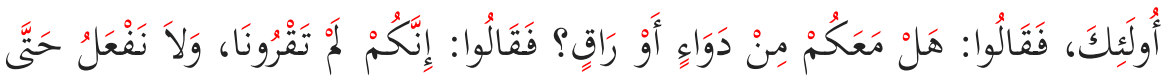

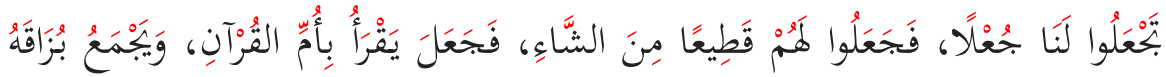

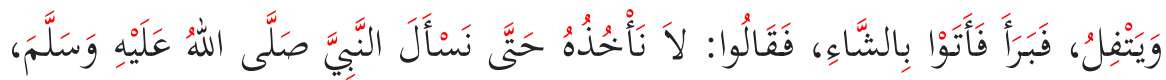

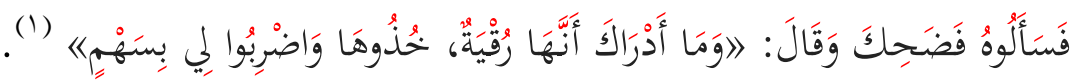

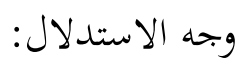

أن البي

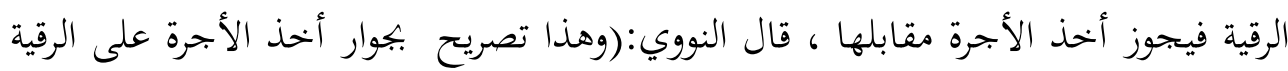

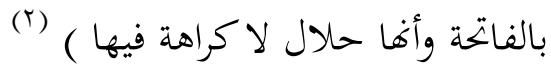

وقال الإمام البغوي : (في الحديث دليل على جواز الرقية بالقرآن وأخذ الأجرة عليه ) (r).

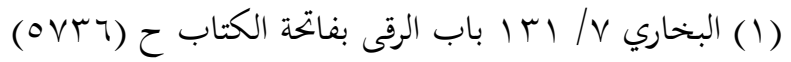

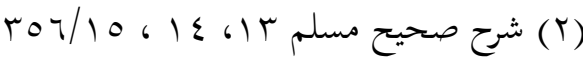

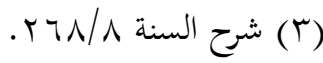


1 - أن لأخذهم الجعل سببا ، وهو أن هؤلاء بخلاء فعوقبوا بنقيض مقصدهم ، والجزاء

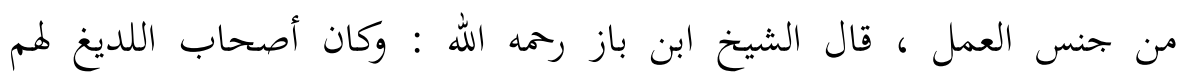
يضيفوهم فلهذا شرطوا عليهم الجعل). (1) ץ- أهم لم يتخذوا ذلك مهنة بعد ذلك ، ولو كان ذلك مشروعاً لسبقونا إليه وهم

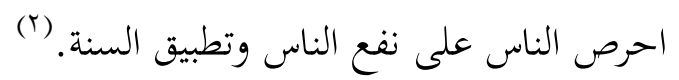
r- أن القوم اشترطوا أن يجعل لهم جعلاً ، فاستحقوا الأجرة بعد أن نشط سيد القوم.(r)

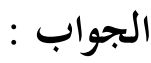
قد يكون المعطى من الأجر على الرقية من باب الإجارة وقد يكون من باب الجعالة فإذا

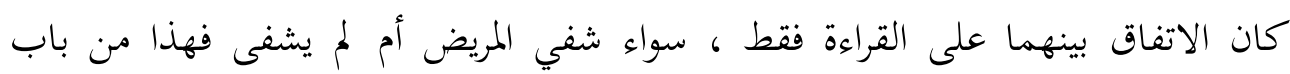

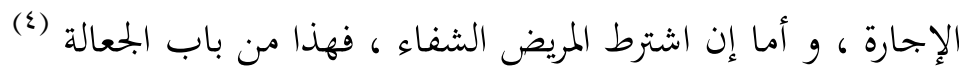
r- عن عم خحارجه بن الصلت التميمي رضي الله عنه أنه أتى رَسُولُ اللَّهِ صَلَّى اللَّهُ عَلَّْهِ

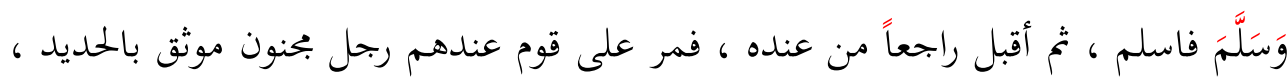
فقال أهله كان حدثنا ان صاحبكم هذا قد جاء بخير فهل عندك شيء تداويه ؟ فرقيته بفاتحة

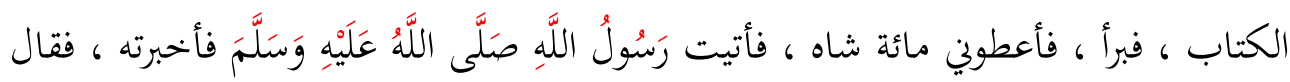

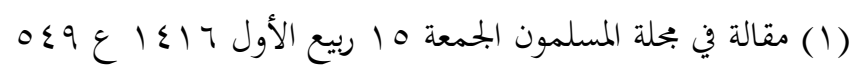

$$
\begin{aligned}
& \text { (Y) الشيخ صالح السحيمي فتوى مسجلة موقع جامع الدروس العلمية }
\end{aligned}
$$

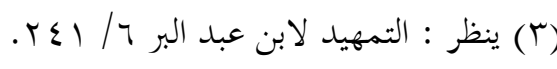

$$
\begin{aligned}
& \text { (ع) ينظر : أحكام الرقى والتمائم ص و V، د. د. فهد السحيمي. }
\end{aligned}
$$


هل إلا هذا وقال مسدد في موضع آخر ( هل قلت غير هذا ) قلت : لا قال:(خذها ، فلعمري لمن أكل برقية باطل، لقد أكلت برقيه حق) (').

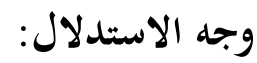
أجاز الرسول عليه الصلاة و السلام أخذ الأجرة على الرقية ،وبيع ما نفث فيه بالرقية نوع من الرقية فيباح أخذ الأجرة عليه.

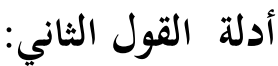

1 - أنه لم يثبت عن الصحابة أو السلف الصالح ذلك الفعل ، ولم يتخذ أحداً منهم الرقية طريقا للتكسب ، وقد سئل الإمام أحمد عن الرجل يكتب التعاويذ من القرآن وغيره يبيعها ، قال أكرهه (r)

Y- توسع بعض الرقاة في هذا المجال على نحو ما نراه ونسمعه في هذه الأيام ، فهو عين الظلم، وأكل اموال الناس بغير حق ، واتخاذ الرقية الشرعية وسيلة للتجارة ، فتغيرت النية لدى كثير ممن سلك هذا المسلك وتبدل حالهم ، فأصبح الربح والتجارة هي الغاية ، وقد سئل الشيخ عبد الله بن جبرين رحمه الله عن الحلكم الشرعي في بيع الماء والزيت المقروء عليه ، ونحو ذلك من أمور أخرى وبأسعار قد تكون خيالية في بعض الاحيان ، فأجاب :(الواقع إن الذين يبيعون الماء ونحوه بعدما ينفثون فيه قليلاً، أن

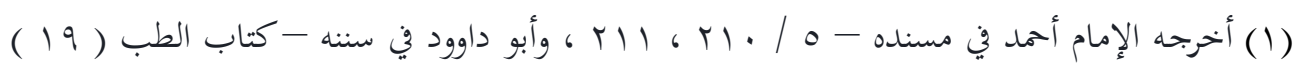

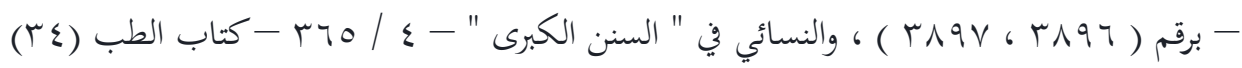

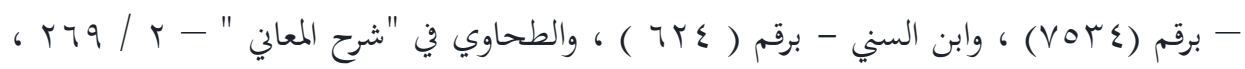

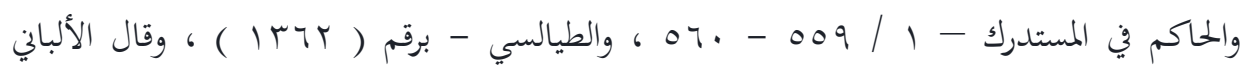

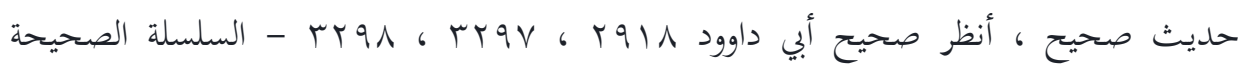
T. TV

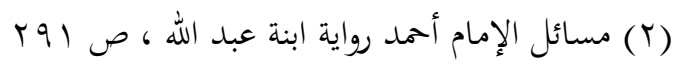




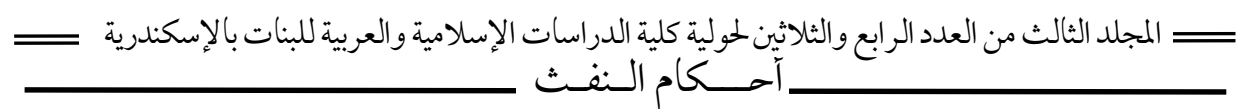

ذلك الماء قليل التأثير و الفائدة ، حيث أن الراقي لم يقصد من قراءته في هذا الماء أو

الزيت ونوه إلا الدنيا والمصلحة الشخصية ). (1)

\section{الراجح:}

مما سبق يترجح عندي جواز أخذ الأجرة على بيع ما نفث فيه بالرقية الشرعية ، على أن لا

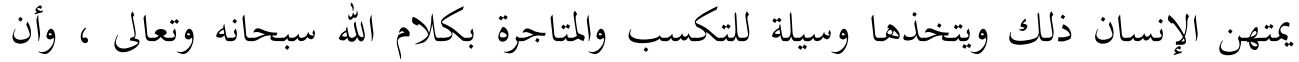

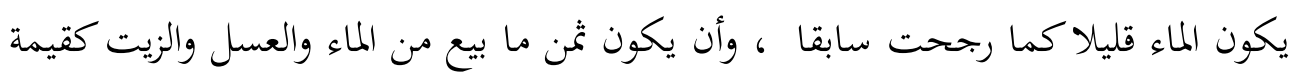

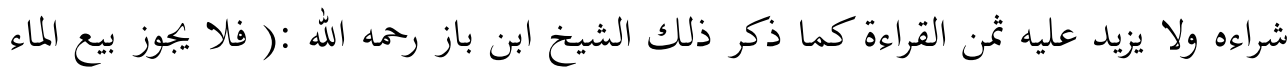

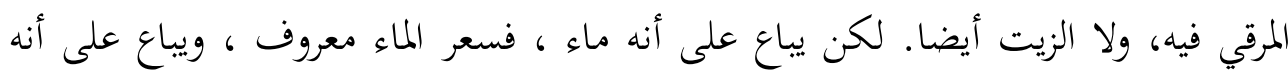

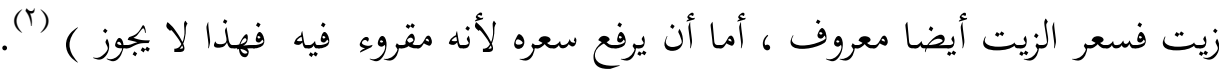

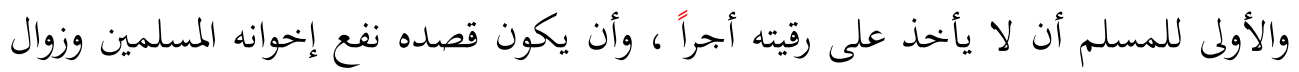

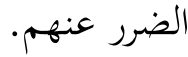

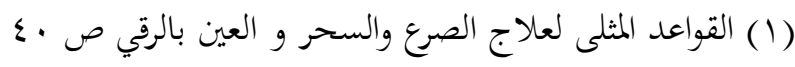

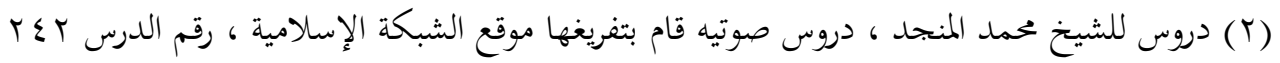




\section{المبحث الخامس}

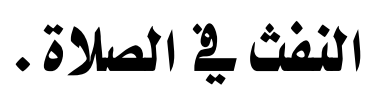

وفيه مطلبان :

المطلب الأول: النفث في الصلاة للمنفرد.

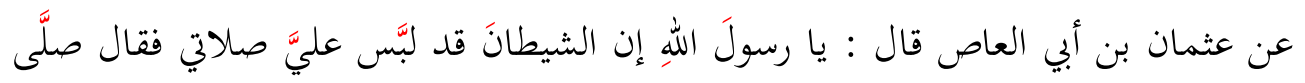

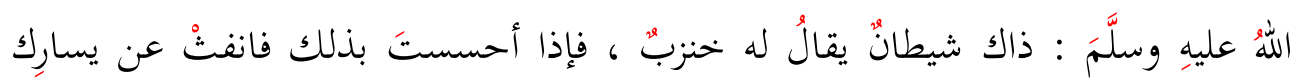

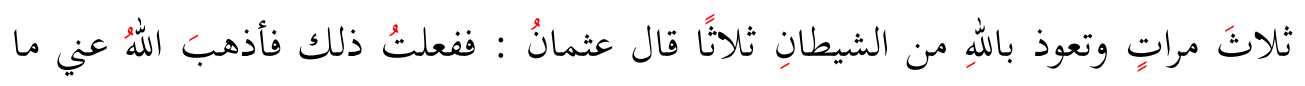

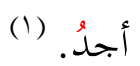

$$
\text { وعند مسلم : ( واتفل عن يسارك ثلاثاً ) (r). }
$$

ففي هذا الحديث ارشاد للمسلم إذا أحس بوسوسة الشيطان له في الصلاة ، وأن أن يتعوذ بالله

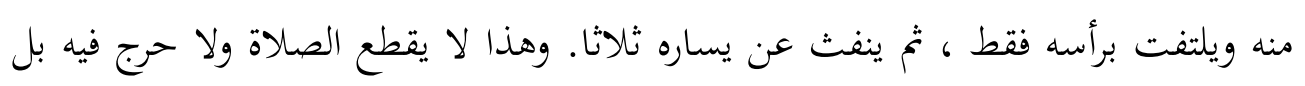

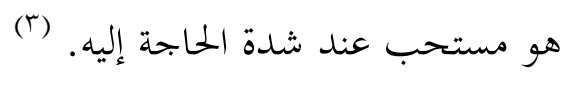

والمتأمل في روايات هذا الأدب من الأحاديث يلحظ أنه قد ورد الأمر بالنفث والتفل ، فلعل المراد أن ينفخ العبد مع شيء يسير من الريق.

المطلب الثاني : النفث في صلاة الجماعة. في المطلب السابق ذكرت حديث عثمان بن العاص عن الاستعاذة من الشيطان والنفث في الصلاة في حالة المنغردة. فكيف يكون النفث أو التفل في صلاة الجماعة ؟

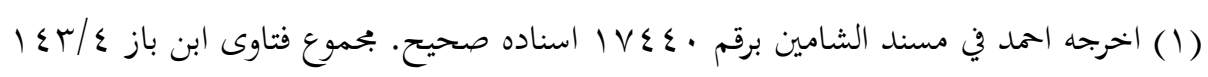

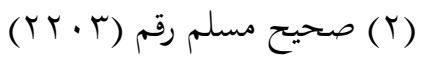

$$
\begin{aligned}
& \text { (r) بحموع فتاوى ابن باز }
\end{aligned}
$$




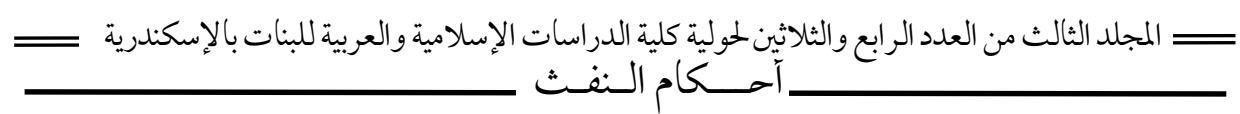

ذكر الشيخ ابن عثيمين أنه إن كان آخر واحد على اليسار وأمكنه أن يتفل عن يساره ، وإلا فليتفل عن يساره في ثوبه في غرته في منديل فإن لم يتيسر هذا كفى أن يلتفت عن يساره ويقول أعوذ بالله من الشيطان الرجيم حتى لا يؤذي من حوله. (1)

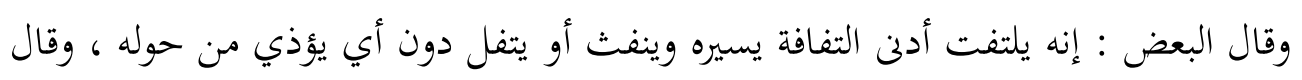

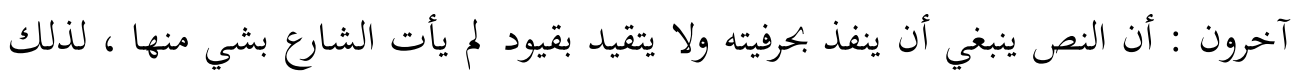
يمكنه النفث أو التفل عن يساره تحت قدمه ولا يؤذي من حوله (r). 


\section{المبحث السادس \\ النفنث عنل رؤية ما يكره بِّ المثنام}

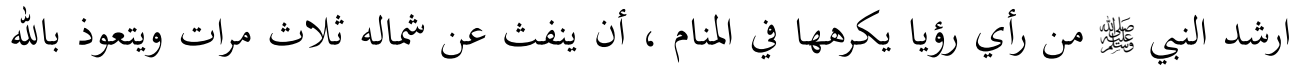
من الشيطان.

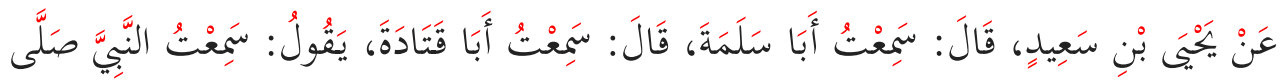

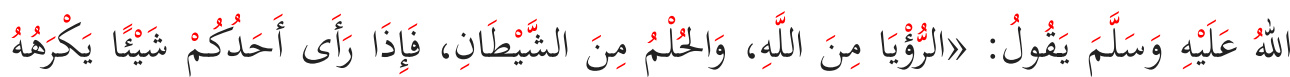

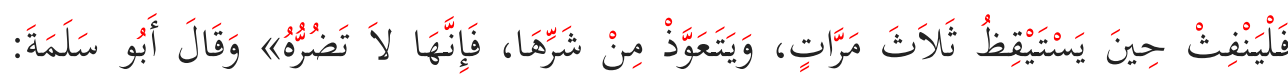

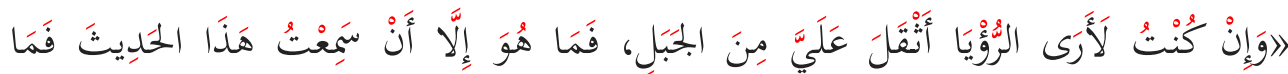

$$
\text { (1) أُبَالِيهَاهان }
$$

وعند مسلم ( فليتفل عن يساره ثلاثاً ، ويتعوذ من شر الشيطان ، ولا يحدث بها احد فإنها (r) لن تضره ) وعند البخاري في رواية ( فليبصق عن يساره وليتعوذ بالله من شرها (“) ). والمتأمل في روايات هذا الأدب من الأحاديث يلحظ أنه قد ورد الأمر بالنفث والتفل

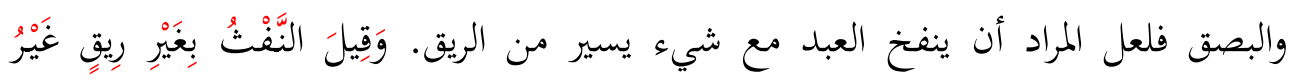

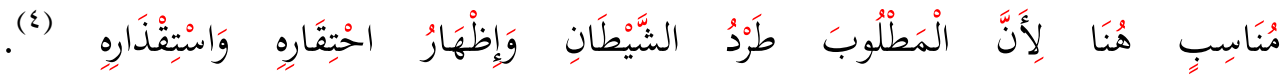

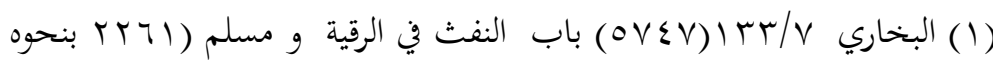

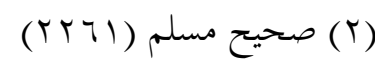

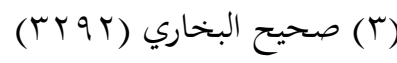

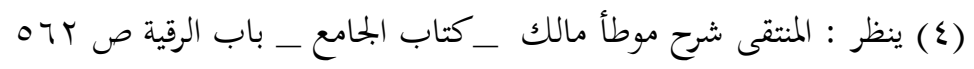




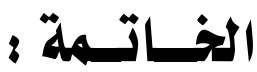

نحل من مذا البحث إلى نتائج وتوصيات من أهها :

ا ـأن المراد بالنفث نفخ لطيف بلا ريق أو بريق خفيف وهو أقل من التفل.

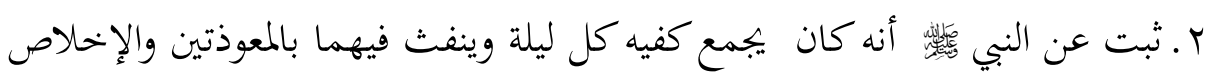

$$
\text { ويمسح ما استطاع من جسده ثلاث مرات. }
$$

r. ثبت عن النبي

$$
\text { أحد من أهله نفث عليه أيضاً. }
$$

ـ ـ أن النفث يمكن أن يكون قبل القراءة أو بعدها فالأمر في ذلك واسع.

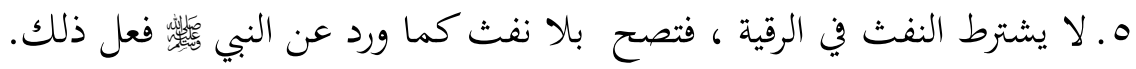

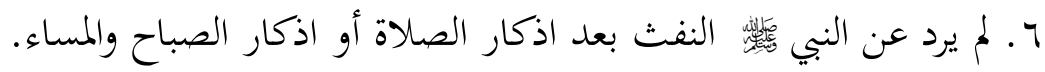
V.اختلف العلماء في حكم النفث في الماء ثم شربه والاغتسال به ورجحت الجواز لفعل السلف ذلك.

^.لا ينبغي التوسع في أمر الرقية الشرعية واتخاذها مهنة ووسيلة للتكسب ، ولا النفث

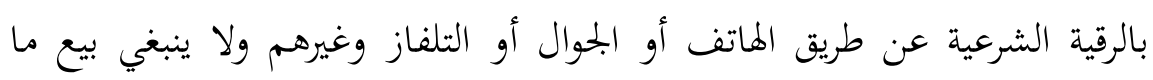

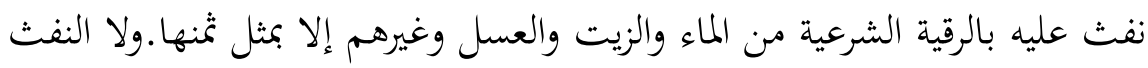

$$
\text { في الخزانات أو الكميات الكبيرة من الماء. }
$$

9 . لا ينبغي للنافث أن ينفث إذا علم أن به مرضاً معدياً.

• 1. إذا أحس المسلم بوسوسة الشيطان له في الصلاة فإنه ينفث عن يساره أو يتفل برصال

$$
\text { ثلاث مرات مع الاستعاذة بالله من الشيطان الرجيم. }
$$

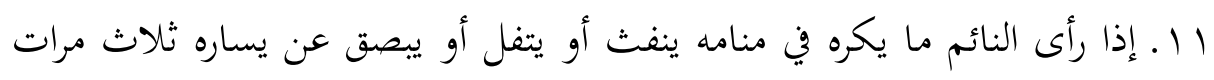

$$
\text { ويستعيذ بالله من شرها. }
$$




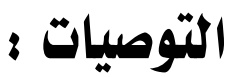

1. توعية الناس بأن يرقي الإنسان نفسه ، أو ليكن الزوج هو الراقي لزوجته وأسرته،

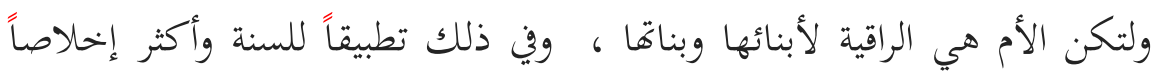

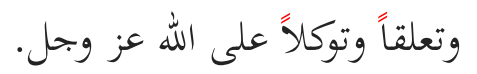
Y. أن يكون عمل جميع الرقاة تحت مظلة حكومية أو جهة إشراقية أو حتى رقابية،

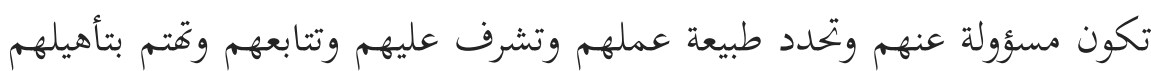
، للحد من حدوث التجاوزات والمخالفات الشرعية r. على وزارة الصحة مسؤولية الكشف الطبي على الرقاة الذين ينفثون في المياه أو الزيوت ، ومنحهم شهادات صحية بخلوهم من الأمراض ، حتى لا يتم نقل العدوى إلى الناس بسببها كأمراض الصدر وغيرها من الأمراض الخطيرة. 


\section{المراجـيـا}

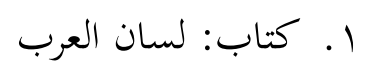

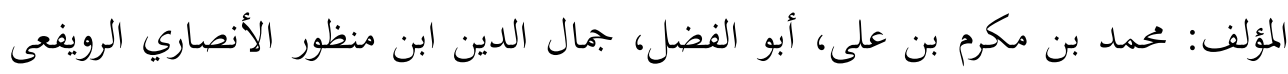

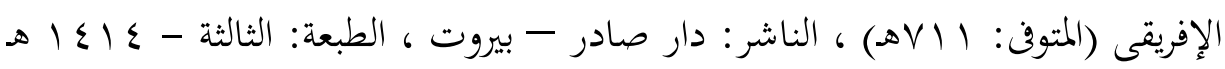

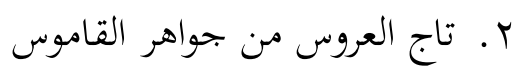

المؤلف: محمّد بن محمّد بن عبد الرزّاق الحسيني، أبو الفيض، الملقّب بمرتضى، الزَّبيدي

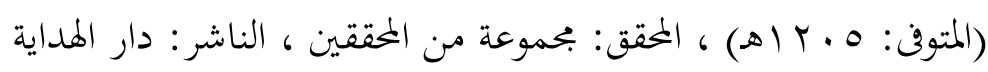
r. (ن. مختار الصحاح

المؤلف: زين الدين أبو عبد الله محمد بن أبي بكر بن عبد القادر الحنفي الرازي (المتوفى: (⿻747

المعق: يوسف الشيخ محمد ، الناشر: المكتبة العصرية - الدار النموذجية، بيروت - صيدا

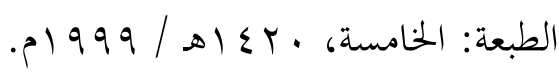
ع. معجم لغة الفقهاء

المؤلف: محمد رواس قلعجي - حامد صادق قنببي ، الناشر: دار النفائس للطباعة والنشر

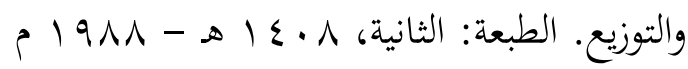
ه. شرح الزرقاني على المواهب اللدنية بالمنح المحمدية.

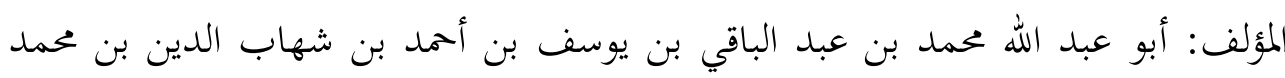

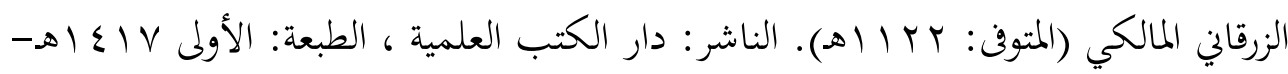

$$
\text { 7. النهاية في غريب الحديث والأثر }
$$

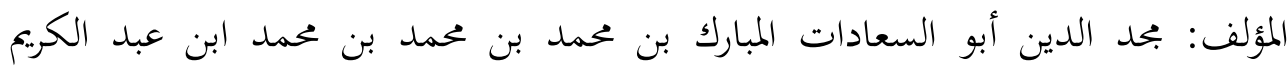

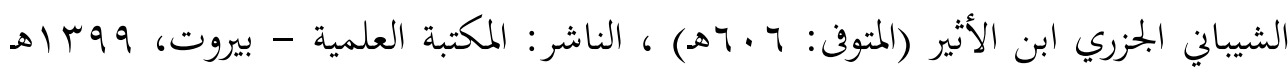

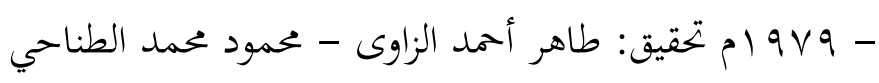




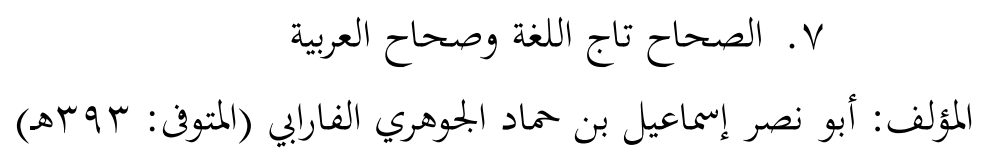

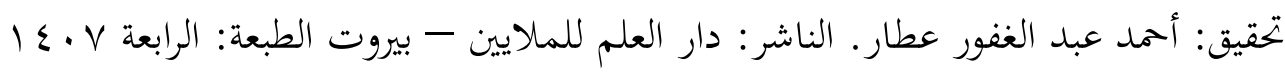

$$
\text { b } 191 \mathrm{~V}-\infty
$$

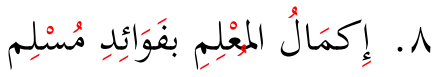

المؤلف: عياض بن موسى بن عياض بن عمرون اليحصبي السبتي، أبو الفضل (المتوفى:

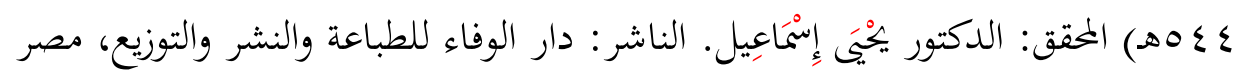

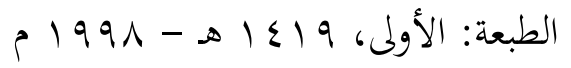

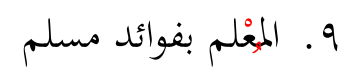

المؤلف: أبو عبد الله محمد بن علي بن عمر التَّميمي المازري المالكي (المتوفى: بسمهـ)

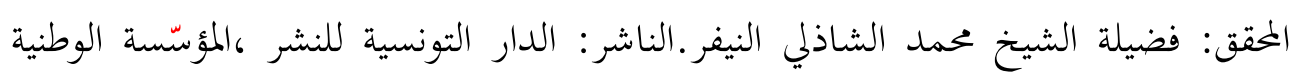

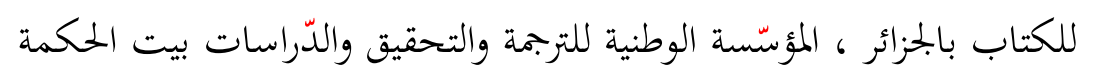

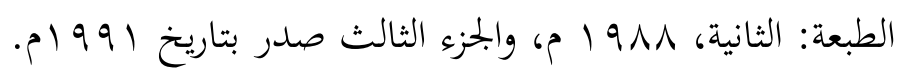
• 1 . كشف المشكل من حديث الصحيحين

$$
\begin{aligned}
& \text { المؤلف: جمال الدين أبو الفرج عبد الرحمن بن علي بن حممد الجوزي (المتوفن: } 90 \text { Vهـ) } \\
& \text { المحقق: علي حسين البواب.الناشر: دار الوطن - الرياض } \\
& 11 \text {. . فيض القدير شرح الجامع الصغير }
\end{aligned}
$$

المؤلف: زين الدين محمد المدعو بعبد الرؤوف بن تاج العارفين بن علي بن زين العابدين

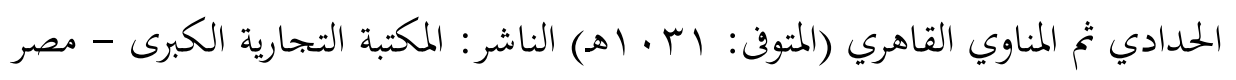

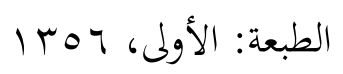

$$
\text { r إ. . شرح سنن أبي داود }
$$

المؤلف: عبد المحسن بن حمد بن عبد المحسن بن عبد الله بن حمد العباد البدر. مصدر الكتاب: دروس صوتية قام بتفريغها موقع الشبكة الإسلامية 
http://www.islamweb.net

$$
\text { r ا. شرح مختصر خليل للخرشي }
$$

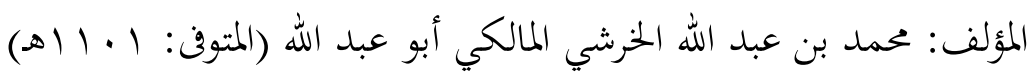

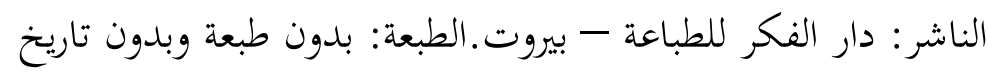

$$
\text { ع ا. القاموس المخيط }
$$

المؤلف: بحد الدين أبو طاهر محمد بن يعقوب الفيروزآبادى (المتوفى:

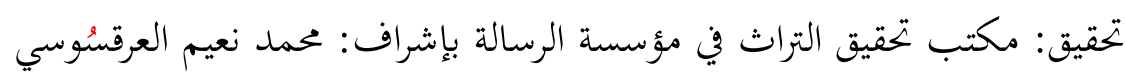
الناشر: مؤسسة الرسالة للطباعة والنشر والثوزيع، بيروت - لبنان

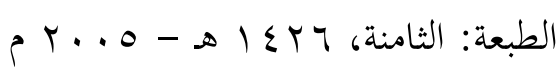
10 . . صحيح وضعيف سنن ابن ماجة

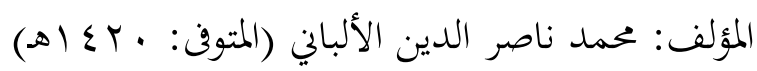

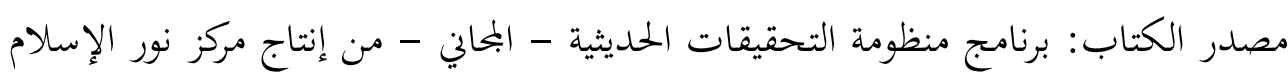

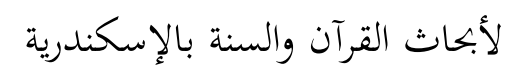

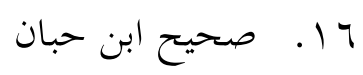

المؤلف: محمد بن حبان بن أحمد بن حبان بن معاذ بن مَعْبَدة، التميمي، أبو حاتم، الدارمي،

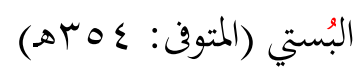

حققه وخرج أحاديثه وعلق عليه: شعيب الأرنؤوط الناشر: مؤسسة الرسالة، بيروت الطبعة:

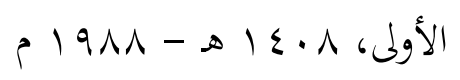

$$
\text { IV }
$$

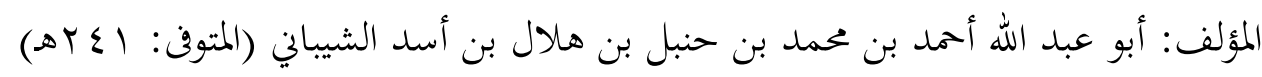

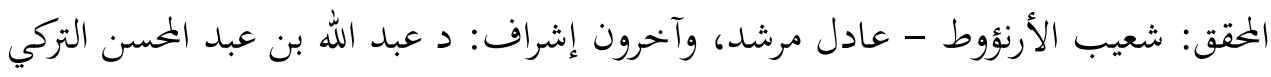

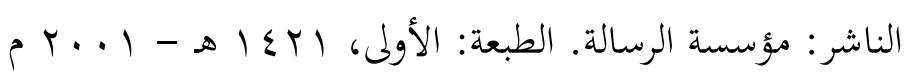


1 ا. ـ المسند الصحيح المختصر بنقل العدل عن العدل إلى رسول الله صلى الله

$$
\text { عليه ووسلم }
$$

المؤلف: مسلم بن الحجاج أبو الحسن القشيري النيسابوري (المتوفى: الب هـ) المحقق: محمد

$$
\begin{aligned}
& \text { فؤاد عبد الباقي.الناشر: دار إحياء التراث العربي - بيروت } \\
& 9 \text { 1 . . عمدة القاري شرح صحيح البخاري }
\end{aligned}
$$

المؤلف: أبو محمد محمود بن أحمد بن موسى بن أحمد بن حسين الغيتابى الحنفى بدر الدين

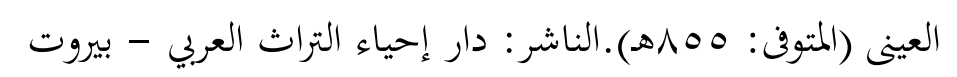
• · . . الجحامع المسند الصحيح المختصر من أمور رسول الله صلى الله عليه وسلم وسننه وأيامه = صحيح البخاري.المؤلف: محمد بن إسماعيل أبو عبدالله البخاري الجعفي.المحقق: محمد زهير بن ناصر الناصر

الناشر: دار طوق النجاة (مصورة عن السلطانية بإضافة ترقيم ترقيم محمد فؤاد عبد الباقي)

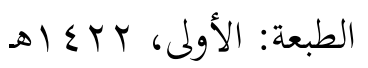

$$
\text { آץ. فتح الباري شرح صحيح البخاري }
$$

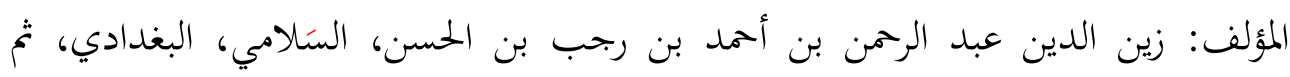

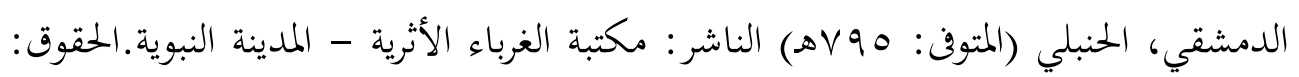

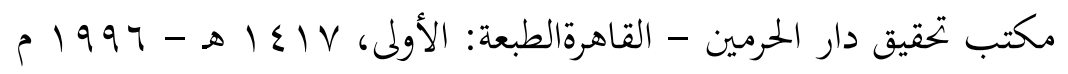

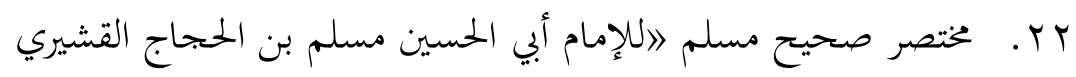

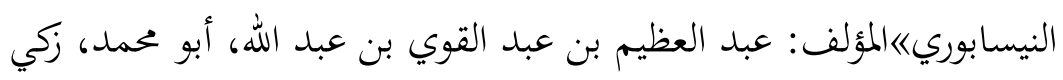
الدين المنذري (المتوفى: 70 7 هـ)المعق: محمد ناصر الدين الألباني.الناشر:

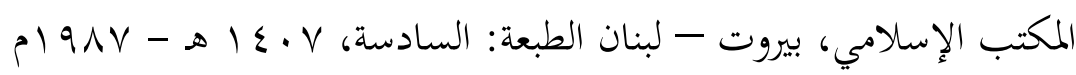

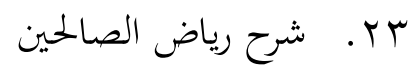
المؤلف: محمد بن صالح بن محمد العثيمين (المتوفن: ابY اهـ)الناشر: دار الوطن للنشر،

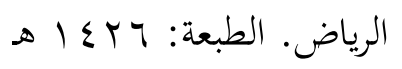




$$
\text { ع r. . تحفة الأحوذي بشرح جامع الترمي }
$$

المؤلف: أبو العلا عحمد عبد الرحمن بن عبد الرحيم المباركفورى (المتوفى: بهم اهـ)

$$
\text { الناشر: دار الكتب العلمية - بيروت }
$$$$
\text { مr. - ميل الأوطار. }
$$

المؤلف: محمد بن علي بن محمد بن عبد الله الشوكاني اليمني (المتوفى: . ه ب اهـ)

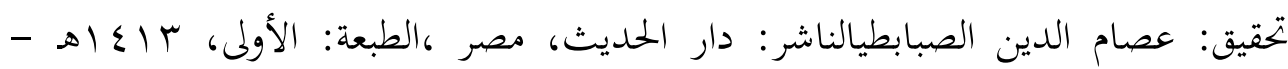

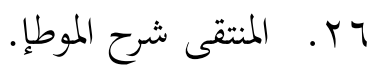

المؤلف: أبو الوليد سليمان بن خلف بن سعد بن أيوب بن وارث التجيبي القرطبي الباجي

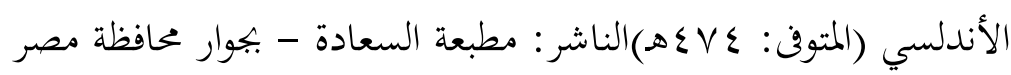

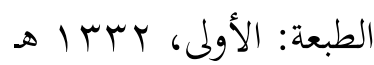

$$
\text { TV }
$$

المؤلف: سليمان بن أحمد بن أيوب بن مطير اللخمي الشامي، أبو القاسم الطبراني (المتوفى: . . بهـ) ،المحقق: طارق بن عوض الله بن محمد ، عبد المحسن بن إبراهيم الحسيني

$$
\text { الناشر: دار الحرمين - القاهرة }
$$

المؤلف: محمد بن علي بن محمد بن عبد الله الشوكاني اليمني (المتوفى: . ه ب اهـ)

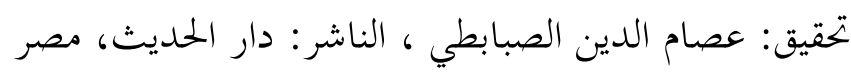

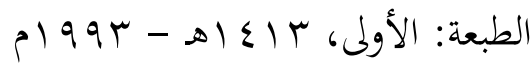

$$
\text { 9 r . المنهاج شرح صحيح مسلم بن الحجاج }
$$

المؤلف: أبو زكريا محيى الدين يهيى بن شرف النووي (المتوف: 7VTهـ

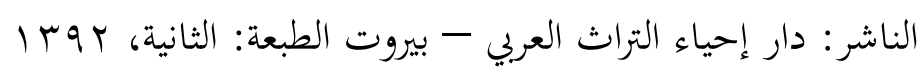
• ب. التمهيد لما في الموطأ من المعاني والأسانيد. 
المؤلف: أبو عمر يوسف بن عبد الله بن محمد بن عبد البر بن عاصم النمري القرطبي

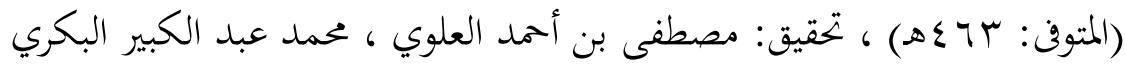

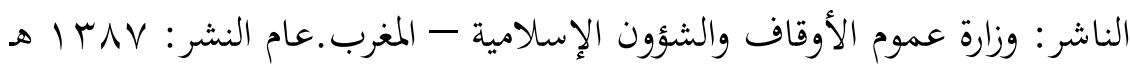
ابr. الجامع لأحكام القرآن (تفسير القرطبي)

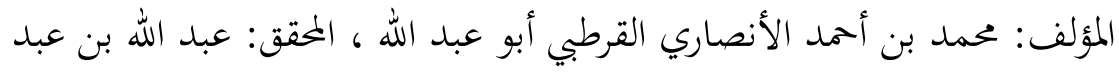

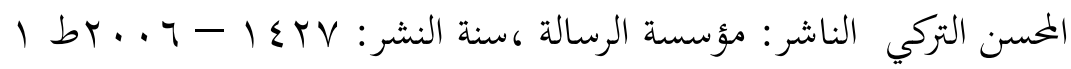

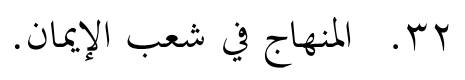

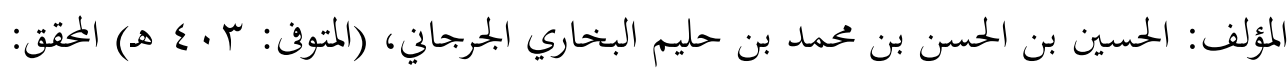

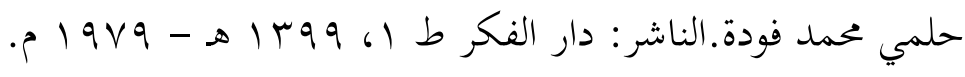
rr. شرح صحيح البخارى لابن بطال.

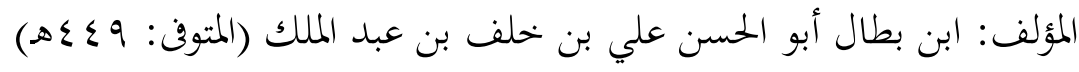

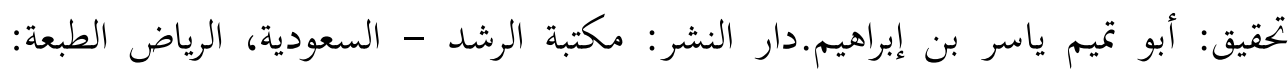

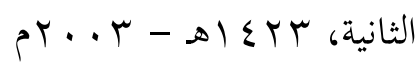
ع ب. أحكام الرقى والتمائم.

المؤلف: د.فهد بن ضويان السحيمي كتاب الكتروين على الشبكة العنكبوتية. هr. مفاتيح الغيب = التفسير الكبير

المؤلف: أبو عبد الله محمد بن عمر بن الحسن بن الحسين التيمي الرازي الملقب بفخر الدين

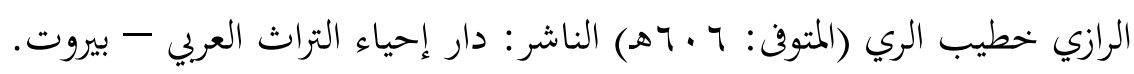

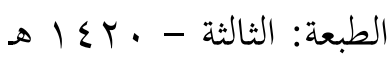
بr. الزوائد ومنبع الفوائد

المؤلف: أبو الحسن نور الدين علي بن أبي بكر بن سليمان الهيثمي (المتوفى: V. Vهـ)

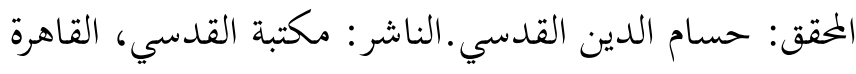




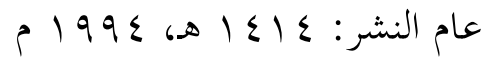
V V. القائد إلى تصحيح العقائد

المؤلف: عبد الرحمن بن يهيى بن علي بن حممد المعلمي العتمي اليماني (المتوفى: بحم اهـ)

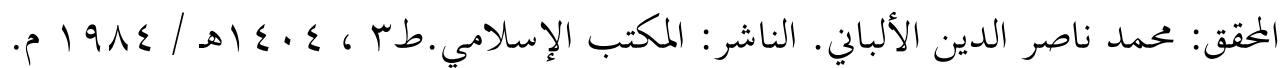
مץ. إتحاف الخيرة المهرة بزوائد المسانيد العشرة

المؤلف: أبو العباس شهاب الدين أحمد بن أبي بكر بن إسماعيل بن عثمان البوصيري الشافعي (المتوفى: · ع ^هـ) المققق: دار المشكاة للبحث العلمي بإشراف أبو تميم ياسر بن إبراهيم

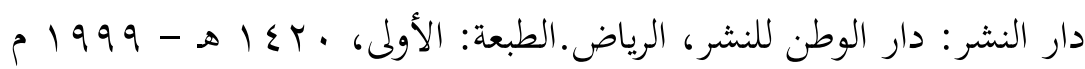
و r. الآداب الشرعية والمنح المرعية

المؤلف: محمد بن مفلح بن محمد بن مفرج، أبو عبد الله، شمس الدين المقدسي الرامينى ثم

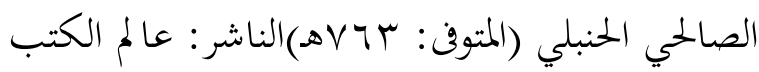
• ع. زاد زاد المعاد في هدي خير العباد المؤلف: محمد بن أبي بكر بن أيوب بن سعد شمس الدين ابن قيم الجوزية (المتوفى: اهنها الناشر: مؤسسة الرسالة، بيروت - مكتبة المنار الإسلامية،

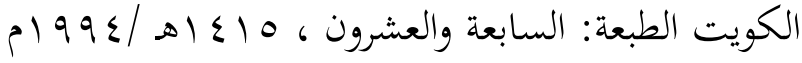

$$
\begin{aligned}
& \text { اء . مدارج السالكين بين منازل إياك نعبد وإياك نستعين }
\end{aligned}
$$

المؤلف: محمد بن أبي بكر بن أيوب بن سعد شمس الدين ابن قيم الجوزية (المتوفى: 10ها لهـ)

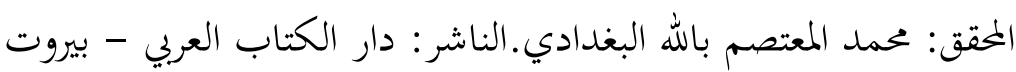
الطبعة: الثالثة، 7 إئ 1 هـ - 1997

r ع . بمموع فتاوى ورسائل فضيلة الشيخ محمد بن صالح العثيمين المؤلف : محمد بن صالح بن محمد العثيمين (المتوفى : اب \& (ه)جمع وترتيب : فها بن ناصر بن إبراهيم السليمان الناشر : دار الوطن - دار الثريا.الطبعة : الأخيرة - باعـ الهـ 


$$
\text { rی }
$$

المؤلف:أبو الحسن نور الدين علي بن أبي بكر بن سليمان الهيثمي (المتوفن:

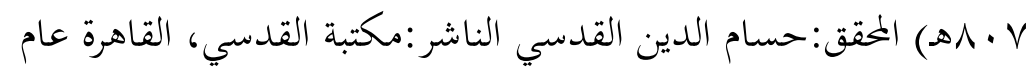

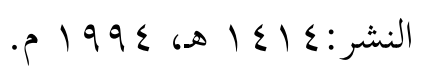

ع ـ . سلسلة الأحاديث الصحيحة وشيء من فقهها وفوائدها

المؤلف: أبو عبد الرحمن محمد ناصر الدين، بن الحاج نوح بن بحاتي بن آدم، الأشقودري

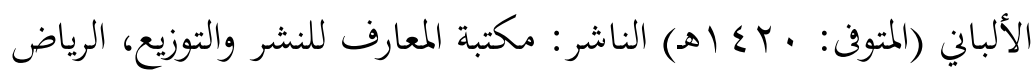

$$
\text { الطبعة: الأولى، (لمكتبة المعارف) }
$$

هـ ـ. ارواء الغليل في تخريج أحاديث منار السبيل

المؤلف : محمد ناصر الدين الألباني (المتوفى : · بـاهـ) إشراف: زهير الشاويش.الناشر:

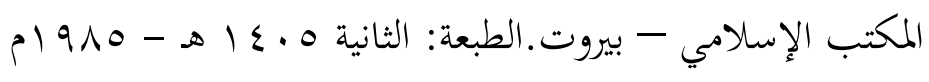

$$
\text { Tـ . . مشكاة المصابيح }
$$

المؤلف: محمد بن عبد الله الخطيب العمري، التبريزي (المتوفى: إهـ) المحقق: محمد ناصر

$$
\begin{aligned}
& \text { الدين الألباني.الناشر: المكتب الإسلامي - بيروت طس، } 1910 \\
& \text { V V . صحيح الجامع الصغير وزياداته }
\end{aligned}
$$

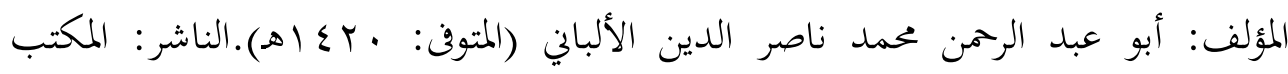

^乏. ـ مسائل الإمام ابن باز رحمه الله تعالى

المؤلف: عبد العزيز بن عبد الله بن باز (المتوفى: · بـ اهـ) تقييد وبمع وتعليق: الشيخ أبي محمد عبد الله بن مانع.الناشر: دار التدمرية، الرياض - المملكة العربية السعودية الطبعة: الأولى، 9ـ ـ. الكتاب المصنف في الأحاديث والآثار 
المؤلف: أبو بكر بن أبي شيبة، عبد الله بن محمد بن إبراهيم بن عثمان العبسي (المتوفى: هrrهـ.المققق: كمال يوسف الحوت.الناشر: مكتبة الرشد - الرياض الطبعة: الأولى،

$1 \varepsilon \cdot 9$

ـ.

المؤلف: اللجنة الدائمة للبحوث العلمية والإفتاء جمع وترتيب: أحمد بن عبد الرزاق الدويش

$$
\text { (01 }
$$

المؤلف: محيي السنة، أبو محمد الحسين بن مسعود بن محمد بن الفراء البغوي الشافعي (المتوفى: 7 (0)هـ) تحقيق: شعيب الأرنؤوط-محمد زهير الشاويش.

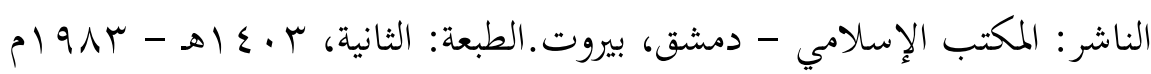

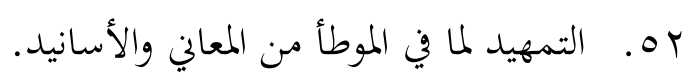

المؤلف: أبو عمر يوسف بن عبد الله بن محمد بن عبد البر بن عاصم النمري القرطبي (المتوفى: با7§ه) تحقيق: مصطفى بن أحمد العلوي ، محمد عبد الكبير البكري الناشر: وزارة عموم الأوقاف والشؤون الإسلامية - المغرب.عام النشر: Vم ا هـ rه. مسائل أحمد بن حنبل رواية ابنه عبد الله ورأل

المؤلف: أبو عبد الله أحمد بن محمد بن حنبل بن هلال بن أسد الشيباني (المتوف: إع هـ)

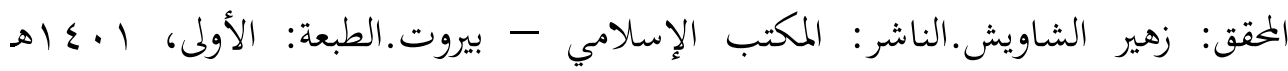

$$
\text { عه. فـ فئاوى نور على الدرب. }
$$

للشيخ : محمد بن عثيمين. المكتبة الشاملة.

$$
\text { هـ. فتاوى نور على الدرب]. }
$$

المؤلف: عبد العزيز بن عبد الله بن باز (المتوفى: · بـ اهـ) جمعها: الدكتور محمد بن سعد الشويعر. المكتبة الشاملة. 


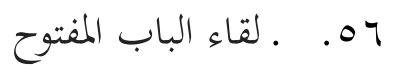

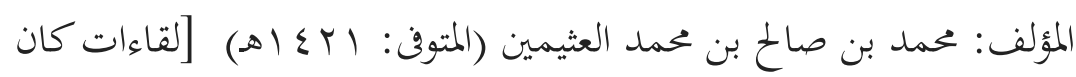

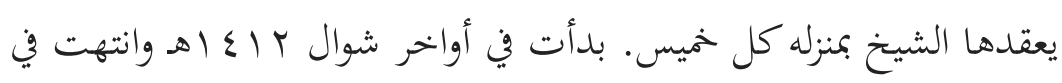
الخميس ع ا صفر، عام اب \& اهـ]مصدر الكتاب: دروس صوتية قام http://www.islamweb.net بتفريغها موقع الشبكة الإسلامية OV

المؤلف: محمد بن صالح بن محمد العثيمين (المتوفن: ابץ إه)جمع وترتيب: فهد بن ناصر بن إبراهيم السليمان الناشر: دار الوطن - دار الثريا.الطبعة:

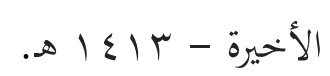

هـ ـ مجموع فتاوى العلامة الألباني.

جمع وترتيب: أبو سند فتح الله. المكتبة الشاملة.

$$
\text { وهـ. الفوائد العلمية من الدروس البازية. }
$$

تأليف : العلامة الشيخ عبدالعزيز بن عبدالله بن باز. الناشر دار الرسالة

$$
\text { . . . . التداوي بلا دواء. المشق }
$$

د. أمين رويحة دار القلم - بيروت - لبنان الطبعة: السابعة مزيدة ومنقحة

$$
\text { الج. الأجوبة الجامية على الأسئلة السلفية }
$$

سلسلة محاضرات للشيخ محمد أمان الجامي ، N/1 أشرطة مفرغة على الى الى

$$
\text { ملفات وورد }
$$

T T. . من اعجاز القرآن و السنة في الطب الوقائي د. عبد الجواد الصاوي باحث

$$
\text { في الميئة موقع الهيئة على الشبكة العنكبوتية }
$$


با7. الطب الوقائي في السنة النبوية بحث مقدم الى جامعة الخرطوم لنيل

ماجستير الأداب في الدراسات الإسلامية إعداد/ هند بابكر سليمان، جامعة

$$
\text { الخرطوم } 1999
$$

عا7. فنح الحق المبين في علاج الصرع والسحر والعين.

تأليف : عبدالله بن محمد الطيار ، وسامي بن سليمان المبارك ، دار الوطن :الرياض. ط ب لب

$$
\Delta \leqslant 10
$$

ه7. الزبدة السلفية في الرقية الشرعية لعالم العين والسحر والحان.

$$
\text { لعدد من العلماء الأفاضل : }
$$

عبد العزيز بن باز رحمه الله ، محمد بن ناصر الدين الألباني رحمه الله ، محمد بن صالح العثيمين رحمه الله ، محمد بن ابراهيم آل الشيخ رحمه الله ، أبي نصر محمد بن عبد الله حفظه الله ، صالح بن فوزان الفوزان حفظه الله ، عبد المحسن العباد حفظه الله ،اللجنة الدائمة للبحوث العلمية والإفتاء.كتاب الكتروني على موقع شبكة الألوكة. 7 7. أحتح الحق المبين في أحكام رقى الصرع والسحر والعين.

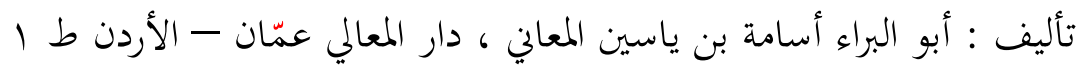

$$
\text { r...- - D } 1 \leqslant r \mid
$$$$
\text { المحلات : }
$$

بحلة الدعوة ، العدد سبه ا ذي القعدة 9 إـاهـ. بحلة المسلمون العدد 9 \&ه ربيع الأول 7 إع ا هـ.

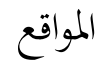
موقع الشيخ الألباني موقع الشيخ ربيع المدخلي. موقع الشيخ خالد المصلح. 